\title{
Innovative methods for biomarker discovery in the evaluation and development of cancer precision therapies
}

\author{
ljeoma Adaku Umelo ${ }^{1}$. Brunella Costanza ${ }^{1} \cdot$ Vincent Castronovo $^{1}$
}

(C) Springer Science+Business Media, LLC, part of Springer Nature 2018

\begin{abstract}
The discovery of biomarkers able to detect cancer at an early stage, to evaluate its aggressiveness, and to predict the response to therapy remains a major challenge in clinical oncology and precision medicine. In this review, we summarize recent achievements in the discovery and development of cancer biomarkers. We also highlight emerging innovative methods in biomarker discovery and provide insights into the challenges faced in their evaluation and validation.
\end{abstract}

Keywords Cancer biomarker · Precision medicine · "omics" · Accessible proteins

\section{Introduction}

Cancer is the leading causes of premature mortality worldwide. In recent years, the overall prevalence and incidence of a wide variety of cancer types has risen considerably and is still expected to increase. Thus, the public health burden of cancer and its economic and social impact cannot be underestimated. Moreover, it is generally well accepted that the efficacy of cytotoxic systemic therapy in the treatment of cancer has reached a therapeutic plateau $[1,2]$. New tools are therefore needed to improve cancer treatment, as well as its screening, diagnosis, and management. Cancer biomarkers have emerged over the last few decades as valuable tools paving the way for personalized medicine [3]. These biological indicators of disease have transformed the molecular landscape of cancer, leading to more efficient disease diagnosis, patient stratification, treatment, and surveillance. In addition, the integration of various multi-dimensional "omic" analytical platforms - genomics, transcriptomics, proteomics, and metabolomics - has undoubtedly revolutionized biomarker discovery by further unraveling the functional and pathological mechanisms of malignant disease. However, despite huge

Ijeoma Adaku Umelo and Brunella Costanza contributed equally to this work.

Vincent Castronovo

vcastronovo@ulg.ac.be

1 Metastasis Research Laboratory, GIGA-Cancer, University of Liège, Bât. B23, avenue de l'Hôpital 3, B-4000 Liège, Belgium advancements in discovery efforts, only a limited amount of cancer biomarkers have been approved for use in the clinical setting. The majority of candidate biomarkers that depict malignant transformation remain poor predictors of disease and treatment outcome, and are thus not reliable clinical tools [4]. In this review, we discuss recent advances in the discovery and development of cancer-associated biomarkers. We also highlight key innovative strategies in drug target discovery and precision medicine. The challenges of tumor heterogeneity in cancer therapy, the accessibility of quantifiable tumor material for biomarker evaluation, and current implications for translational research are also discussed.

\section{Cancer biomarkers}

A cancer biomarker can be broadly defined as an objectively measurable parameter characterizing: (i) a malignant process or (ii) a pharmacological response to therapy. Biomarkers can exist in the form of DNA, RNA, or protein molecules [3], although emerging metabolic approaches are enabling candidate cancer biomarker discovery of various metabolites in both the preclinical [5, 6] and clinical setting [7-9]. Historically, the first cancer biomarkers, tumor specific antigen carcinoembryonic antigen (CEA), and urinary Bence Jones protein were identified in colon carcinoma by the research group of Gold and Freedman [10, 11]. From these pioneering findings, additional biomarkers were subsequently identified in breast cancer (CA15-3), ovarian cancer (CA-125), and other human cancers (CA 19-9) [11]. However, while these classical biomarkers are 
routinely employed in tumor burden assessment, their presence at high concentrations may also be an indicator of other hyperproliferative conditions [12]. Thus, the use of these biomarkers as early detection, predictive or prognostic factors is a large subject of debate, due to their apparent lack of sensitivity and specificity [11-13]. In this section, we summarize the role of classical and novel cancer biomarkers in diagnostic, prognostic, and drug development platforms. It is important to note, however, that some of these biomarkers can overlap. For example, a biomarker identified as a drug target can also have prognostic or diagnostic potential.

\subsection{Diagnostic and prognostic biomarkers}

The clinical outcome of a malignancy considerably improves with early disease detection and diagnosis. Different cancer subtypes have distinct risk factors, clinical presentation, and response to therapy. Thus, the stratification of cancer subtypes based on their biomarker expression pattern is of great importance. In addition, these biomarkers are typically selected based on the molecular profile of the tumor and can therefore influence the selection of therapy in the clinic. A series of clinically relevant cancer biomarkers at their varying "omic" levels are listed in Table 1.

\subsubsection{DNA biomarkers}

Cancer cells exhibit a broad range of genetic variations, which include mutations in oncogenes, tumor suppressor genes, mismatch repair genes (MMR), mitochondrial DNA (mtDNA) [14, 15], as well as single nucleotide polymorphisms (SNPs) and short tandem repeats (STRs). These can serve as biomarkers and can be analyzed using genomic and transcriptomic approaches. For example, mutations in oncogenes such as V-Kiras2 Kirsten rat sarcoma viral oncogene homolog (KRAS) [16, 17] and epidermal growth factor receptor $(E G F R)[16,18]$ have been revealed as predictive factors in malignant disease. KRAS and $E G F R$ driver mutations are shown to increase the risk of metastatic disease in colorectal cancer (CRC) [19] and lung cancer [20, 21]. Currently, KRAS status is the most utilized predictive marker for response to anti-EGFR antibody-based therapies. In metastatic CRC patients, KRAS activating mutations are responsible for the failure of cetuximab- and panitumumab-based therapeutic regimens [17]. These therapeutic approaches have also failed in wild-type KRAS CRC patients harboring mutations for NRAS (neuroblastoma RAS viral oncogene homolog) or BRAF or PIK3CA. The latter are downstream of EGFR and can independently activate the RASRAF-MAPK cascade. In lung cancer EGFR driver mutations predict sensitivity to similar targeted therapy [18]. However, while $E G F R$-mutated lung cancers initially respond to targeted therapy, acquired second-site $E G F R$ mutations can also predict resistance to therapy [22].

TP53 is frequently mutated in human cancers [23], and as such is relevant as a biomarker in a broad spectrum of cancers. Moreover, several lines of clinical evidence have demonstrated that a disrupted TP53 genomic status is associated with failure to standard therapy [24-26]. Similarly, genetic alterations in the cyclin-dependent kinase inhibitor A (CDK2NA) and retinoblastoma $(R B 1)$ tumor suppressor genes have also been linked to metastatic disease and treatment outcome in a number of human cancers [27-29]. In addition to these, breast cancer type 1 susceptibility protein (BRCA1) mutational status is a well-known predictor of treatment benefit to targeted poly [ADP-ribose] polymerase (PARP) therapy in breast cancer [30] and ovarian cancer [31]. Several clinical trials have demonstrated that PARP inhibitors such as olaparib are effective as maintenance therapy in a selected patient sub-group harboring germline or somatic mutant BRCA in their tumor [30].

DNA methylation is one of the most studied epigenetic alterations commonly observed in cancer [32]. The development of sequencing-based high-throughput assay techniques has enabled profiling of the methylome thereby leading to the discovery of candidate cancer-associated markers. In CRC,
Table 1 Cancer biomarkers in clinical use

\begin{tabular}{lllll}
\hline Biomarker & Biomolecule & Specimen & Clinical application & Cancer type \\
\hline EGFR & DNA & Tissue & Prediction/prognosis & NSCLC \\
KRAS & DNA & Tissue & Prediction/prognosis & Colon \\
MSI & DNA & Tissue & Prediction/prognosis & Colon \\
CEA & Protein & Serum & Monitoring & Colon \\
PSA & Protein & Serum & Diagnosis & Prostate \\
c-Kit & Protein & Tissue & Diagnosis & Gastrointestinal \\
HER2-neu & Protein & Tissue & Prediction/prognosis & Breast \\
Estrogen receptor (ER) & Protein & Tissue & Prediction/prognosis & Breast \\
Progesterone receptor & Protein & Tissue & Prediction/prognosis & Breast \\
CTCs (EpCAM, CD45, & Protein & Blood & Prediction/prognosis & Breast \\
cytokeratins 8, 18, 19 & & & & \\
\hline
\end{tabular}

$C E A$ carcinoembryoinc antigen, $N S C L C$ non-small cell lung cancer 
for example, hypermethylated APC, p16INK4a, and TIMP3 genes have been reported as potential biomarkers for early cancer detection [33]. A microarray-based genome-wide DNA methylation analysis performed by Szmida and collaborators [34] has demonstrated a differential methylation status in four ErbB-associated genes (PIK3CD, PKCB, ERBB4, PAK7). In addition, their result revealed that hypermethylation of PKCB was significantly associated with KRAS mutations, whereas hypermethylation of ERBB4 was associated with high-methylation epigenotypes (HME), and BRAF mutations [34]. PKCB regulates cell proliferation and promotes angiogenesis. Therefore, the relationship between DNA methylation and $P K C B$ gene expression has been shown to be an interesting element in the context of CRC chemoprevention and targeted anti-cancer therapy. Recently, the detection of SEPT9 methylation appears to hold promise for the specific diagnosis of CRC [35]. Three assays based on the detection of methylated SEPT9 in blood are being promoted as colorectal cancer screening tests: Epi proColon 1.0 (Epigenomics), ColoVantageTM (Quest Diagnostic), and RealTime ms9 (Abbott).

Microsatellite instability (MSI), a somatic alteration caused by the loss of DNA mismatch repair activity and characterized by a hypermutable phenotype, is another molecular marker with unique prognostic features [36]. Interestingly, the majority of MSI events have been classically found in a distinct pathological subset of colorectal cancer (CRC) and more often have a favorable clinical outcome when detected at early stages $[17,36]$. A subset of CRCs harboring high level MSI (MSI-H) signatures have been reported to specifically exhibit a hypermethylation phenotype caused by methylation of either MMR or non-MMR genes [37, 38]. While several lines of evidence have demonstrated that these MSI profiles are predictive markers for resistance to 5-FU-based chemotherapy $[39,40]$, other studies have shown that they may confer sensitivity to irinotecan and mitomycin [41, 42]. More recently, Hause et al. have identified MSI signatures in 14 other cancer types [43]. Analogous to CRC, the MSI status across these cancer types was generally reported to be a positive prognostic factor [43].

Epigenetic alterations, implicated in the silencing of tumor suppressor genes or transcriptional activation of cancerassociated genes, have also been reported as potential cancer biomarkers. In prostate cancer, it has been demonstrated that differential CpG-island methylation of the glutathione Stransferase $(G S T P 1)$ gene promoter, plays a role in risk stratification $[44,45]$. Promoter region methylation of $\mathrm{O}^{6}$ methylguanine-DNA-methyltransferase (MGMT) in glioblastoma (GBM) is associated with a favorable clinical outcome and can predict response to standard therapy [46]. Histone modifications such as acetylation, deacetylation, and methylation may also be useful in the clinical management of cancer. Although histone modifications have not been fully investigated as potential cancer biomarkers, evidence suggest that specific modification patterns could be important in cancer risk assessment and prognosis [47, 48].

Circulating cell-free DNA (cfDNA) represents a promising source for the detection of cancer-specific genetic alterations [49]. Cell-free DNA is released into biological fluids (blood or urine) by apoptotic/necrotic cancer cells or by lysis of circulating tumor cells (CTCs) [50]. The screening of such fluids can therefore reflect tumor burden and other clinical parameters. It is generally accepted that increased levels of serum cfDNA are indicative of the degree of malignancy, while decreased cfDNA levels are used to monitor response to therapy. Therefore, cfDNA is considered as a valid prognostic factor in a number of human cancers [51-54]. Moreover, several studies have reported significantly higher levels of cfDNA in CRC patients compared to healthy controls [55]. These emerging data thus demonstrate the potential utility of cfDNA as a non-invasive biomarker.

\subsubsection{RNA biomarkers}

In contrast to DNA-based biomarkers which can be molecularly interrogated as individual markers, cancer-associated RNA markers are characteristically assessed as collective biomarker signatures, through analysis of changes in gene expression patterns [56]. This approach can be useful for early disease detection and can hold diagnostic, prognostic, and predictive value [57]. Moreover, the development of highthroughput applications such as transcriptome sequencing (RNA-seq) has enabled the identification of these cancerspecific RNA signatures by measuring the genome-wide expression profile of cancerous versus normal samples. RNA-seq methodologies have low background noise, a large dynamic range, and are highly accurate and reproducible. In addition, RNA-seq-based transcriptome analysis can also differentiate specific cancer types from other cancers [58, 59]. For example, Peng and colleagues have recently demonstrated that a lung cancer-specific gene expression signature containing SFTPA land SFTPA2 genes can accurately distinguish lung cancer from other cancer types [58]. The investigators also reported that SFTPA1 and SFTPA2, described as critical factors in normal lung function [60], have strikingly downregulated gene expression levels in lung tissue compared to adjacent non-tumoral tissue [58].

Disease-specific gene expression signatures can also be obtained with the use of other high-throughput technologies such as microarray [61], serial analysis of gene expression (SAGE) [62], and bead-based microfluidics analysis [63]. In breast cancer, recent clinical guidelines recommend the use of validated multi-gene messenger RNA (mRNA)-based prognostic assays such as OncotypeDx and MammoPrint, which measure the likelihood of disease recurrence as a support to clinical decision-making [64]. Evidence also suggests that 
these diagnostic tests may also predict clinical benefit to standard therapy. The OncotypeDx assay, for example, consists of a 21-gene signature panel that covers several metastatic pathways including MMP11 and GRB7 [65]. In CRC, the ColoPrint assay, comprising an 18-gene signature panel, has been shown to hold great prognostic value for stage II patients and might be useful to drive adjuvant therapy decision in this patient population [66].

Transcriptome analysis of alternative splice-site variants is an active area of biomedical research. Alternative splicing has been implicated in cancer pathogenesis [67] and response to therapy [68], and is therefore a suitable source for biomarker development. For example, the presence of an alternatively spliced androgen receptor variant $7(A R-V 7)$ has been identified in castration-resistant prostate cancer (CRPC) patients and is linked to a reduced response to targeted therapy [69]. Furthermore, EGFR variant III (EGFRvIII) expression has been widely reported in a clinically distinct subset of advanced GBM and is a poor prognostic factor for both overall survival and response to standard anti-EGFR therapy in GBM [70].

RNA-seq analysis is also an essential tool in the quantification of other RNA species, which include long non-coding RNAs (lncRNAs) and small non-coding RNAs such as microRNAs (miRNAs) and picoRNAs (piRNAs). Of note, the overexpression of specific lncRNAs and differentially expressed lncRNAs patterns have been examined as prospective biomarkers in cancer management. Wang et al. recently suggest that a unique 12-lncRNA signature is a negative prognostic factor in breast cancer [71], while Presner et al. demonstrate that the lncRNASChLAP1 is a potential marker for metastatic progression in prostate cancer [72]. In similar fashion, the lncRNA $P C A 3$ has received indication as a valid diagnostic biomarker in prostate cancer. $P C A 3$ is elevated in over $90 \%$ of prostate cancers and is therefore an established tool in prostate cancer screening $[73,74]$. For the small non-coding RNAs, the best described candidate biomarkers are miRNAs. miRNAs derived from tissue or plasma can be profiled via small RNA-seq [75]. Using the small RNA-seq technology, miRNA signatures associated with poor clinical outcome have been compiled for prostate cancer [76], lung cancer [77], osteosarcoma [78], and other cancer types [75, 79]. Importantly, circulating miRNAs derived from biological fluids (e.g. miR-141 and miR-375) have been presented as promising diagnostic markers for prostate cancer [80, 81]. The investigations demonstrate a link between miRNA expression levels and adverse risk factors in prostate cancer. In CRC patients, a variety of miRNAs have been investigated for their utility in the diagnostic, prognostic, or predictive setting [82]. For example, Guang-Hui Liu and collaborators [83] measured the levels of five miRNAs (miR-21, miR-31, miR-92a, miR-18a, and miR-106a) in serum samples from $200 \mathrm{CRC}$ patients, 50 advanced adenoma patients, and 80 healthy controls by realtime quantitative polymerase chain reaction. The authors found that miR-21 and miR-92a serum levels have potential value for early detection of CRC. Furthermore, it has also been shown that miR-92a could be of prognostic value in CRC patients [83]. In another study, circulating levels of miR-15b, miR18a, miR-19a, miR-19b, miR-29a, and miR-335 could discriminate CRC patients from healthy controls [84]. miR-19a is also a useful tool to predict resistance to first-line FOLFOX chemotherapy regimen in patients with advanced CRC [85].

\subsubsection{Protein biomarkers}

Similar to the previously discussed RNA-based expression profiling (Section 2.1.2 above), the proteome can also be interrogated for cancer-specific expression profiles with the use of high-throughput proteomic techniques [86]. Interestingly, researchers have recently uncovered a cancer-specific signature derived from the profiling of ribosomal proteins [87]. Indeed, a number of ribosomal proteins have tissue-specific expression patterns. The findings demonstrate that these tissue-specific patterns can be modulated depending on the individual cancer type, pointing to the potential of these signatures in the prognostic setting [87]. Other promising findings have revealed a protein expression signature to drug response in various cancer models [88]. Using shot-gun proteomics, the study identifies a 12-protein EGFR inhibition signature, which includes c-jun, Jagged 1, and Claudin 4 as part of the repertoire [88].

In breast cancer, the estrogen receptor (ER) is the most established protein biomarker for disease classification [89, 90]. Breast tumors with varying ER status intrinsically differ in their accumulation of aberrations at the genomic and transcriptional level [91, 92]. Alterations in the progesterone receptor (PR) and human epidermal growth factor receptor 2 (HER 2) are also routinely employed in breast cancer classification [89]. While ER and PR status play a principal role in clinical decision-making and the selection of hormonal therapy, HER2 status predicts a benefit to targeted therapy [93]. Androgen receptor (AR) status [94], Ki67 proliferation index [95], and topoisomerase II alpha (TOP2A) expression [96] have also been employed as prognostic and predictive markers in breast cancer subtyping. Of note, our research group has recently identified a stromal-derived protein, asporin, as a prognostic factor in breast cancer [97]. Our findings reveal that low asporin expression is associated with decreased overall survival (OS) and metastasis dissemination [97]. In prostate cancer, current clinically approved protein biomarkers are not ideal as they cannot adequately distinguish between patient sub-groups who should receive treatment for the aggressive form and those who should avoid overtreatment for the indolent form. A classic example of this obstacle is the welldescribed prostate specific antigen (PSA). Although PSA status is used as a prostate cancer screening tool, it is limited in its diagnostic capabilities, due to its lack of sensitivity and 
specificity [98]. Several studies have shown that inflammatory and non-cancerous events can elevate PSA levels, leading to false-positive test results during screening [99, 100].

\subsubsection{Metabolic biomarkers}

Like RNA and proteins, metabolites can also be nominated for profiling signatures associated with clinical outcome and management. These signatures which can be detected via differing metabolic profiling modalities generally indicate a modulation in the metabolic process, with levels of amino acids, choline derivatives, tricarboxylic acid cycle intermediates, and among other metabolites being altered [101]. Distinct metabolic profiling signatures with potential predictive and prognostic value have been identified for colon cancer, ovarian cancer [6], breast cancer [102], and bladder cancer [103]. In glioma, mutations affecting isocitrate dehydrogenase (IDH) are associated with a unique metabolic signature [104]. Importantly, another study has revealed that mutant IDH activity drives the production of the oncometabolite (R)-2-hydroxyglutarate (2-HG) [105]. Experimental evidence has shown that $2-\mathrm{HG}$ is present at a minimal range in normal cells. However, in IDHmutant cells, 2-HG concentration levels are reported to be increased by up to 100 -fold compared to levels found in normal cells [106], thereby identifying $2-\mathrm{HG}$ as a candidate metabolite in cancer screening approaches.

\subsubsection{Exosomal biomarkers}

Exosomes are small extracellular vesicles that are secreted by cells into biological fluids such as blood and urine and have been described as valuable tools in disease monitoring. Exosomal proteins have been presented as candidate biomarkers in the clinical management of melanoma [107], lung cancer [108, 109], and other cancers [110]. Among these exosomal proteins, CD63 a member of the tetraspanin family of scaffolding proteins has emerged as a valid marker in cancer diagnosis and prognosis. Investigators have demonstrated that CD63+ exosomes are present at a higher level in malignant cells compared to normal cells $[107,110]$. In the same line, our group has identified myoferlin, a novel exosomal protein, as a potential prognostic marker in breast cancer and pancreatic cancer [111-114]. We have demonstrated that overexpression of myoferlin in triple negative breast cancer (TNBC) is a negative prognostic factor associated with worse overall survival (OS) and metastatic disease [112]. Our findings in pancreatic cancer also reveal a correlation between myoferlin overexpression and a poor clinical outcome [114].

Exosomes that carry extracellular RNA protect them from degradation and these can therefore be used in diagnostic and prognostic platforms [115]. For example, RNA biomarkers such as $P C A 3$ can be detected in exosomes derived from the urine specimens of prostate cancer patients [116]. In addition, exosomes isolated from glioma cells have been found to contain mutant EGFRvIII RNA [117]. Exosomal miRNA has also been shown to have potential value in the clinic. An 8-miRNA diagnostic signature previously identified in the tissue specimens of ovarian cancer patients, has been identified in serumderived exosomes isolated from the same patients [118]. The comparison between tissue-derived exosomes and circulating exosomes in a small cohort of lung cancer also demonstrated comparable miRNA signature patterns between the examined specimens [119].

\subsubsection{Volatile organic compounds}

Breath analysis, a relatively new field of research, is based on the assumption that specific volatile organic compounds (VOCs) are formed as a consequence of altered pathways during cancer initiation and progression [120]. Enhanced glycolysis, ROS accumulation and fatty acid oxidation are some of the biological processes able to alter the production of VOCs. Cancer VOCs originating from tumor cells released into the tumor microenvironment and blood circulation can arrive to the pulmonary epithelium. Therefore, the evaluation of exhaled breath samples (usually containing around 3000 compounds) is a potential source of cancer biomarkers. Breath can be analyzed through non-invasive techniques coupled with mass spectrometry-based approaches. However, the analysis of exhaled breath may be challenging mainly due to the limited knowledge of the biochemical mechanisms that regulate cancer-related VOCs. Another potential challenge is breath sample collection, storage and VOC stability for long-term studies. Interestingly, the presence of cancer cell-derived VOCs in urine gives to this biological fluid a typical odor that can be recognized by trained dogs and thus represents a possible application for this new class of biomarkers. For example, in a study conducted by Cornu and collaborators, a trained dog was able to discriminate between prostatic cancer patients and healthy controls. The test had a sensitivity and specificity of $91 \%$ [121]. In another study, six dogs were trained to identify patients with bladder cancer with a mean success rate of $41 \%$ [122]. However, although VOCs seem to hold great potential in cancer diagnosis, no "universal" tumor marker has been approved for any cancer type to date. Further screening and large-scale studies are therefore mandatory. Table 2 lists some VOCs identified in a number of human cancers.

\subsection{Accessible biomarkers}

The limitations of standard anti-cancer therapy such as high toxicity associated with targeting non-malignant cells has generated a significant need for alternative therapeutic approaches. Indeed, targeted therapeutic strategies that specifically target the tumor site have emerged as viable 
Table 2 Cancer-related volatile organic compounds (VOCs)

\begin{tabular}{|c|c|c|}
\hline VOCs & Cancer type & Reference \\
\hline $\begin{array}{l}\text { Pentanal } \\
\text { Hexanal } \\
\text { Octanal } \\
\text { Nonanal }\end{array}$ & Lung & [123] \\
\hline $\begin{array}{l}\text { Butan-1-ol } \\
\text { 3-Hydroxybutan-2-one }\end{array}$ & Lung & [124] \\
\hline Hexadecanal & Lung & {$[125]$} \\
\hline Dodecane & Lung & [126] \\
\hline $\begin{array}{l}\text { 5-(2-Methylpropyl)nonane } \\
\text { 2,6-Di-tert-butyl-4-methylphenol } \\
\text { 2,6,11-Trimethyldodecane } \\
\text { Hexadecanal }\end{array}$ & Lung & {$[127]$} \\
\hline $\begin{array}{l}\text { 3-Methylhexane } \\
\text { Dec-1-ene } \\
\text { Caryophyllene } \\
\text { Napthalene } \\
\text { Trichloroethene }\end{array}$ & Breast & [128] \\
\hline $\begin{array}{l}\text { 3-Hydroxybutan-2-one } \\
\text { Ethelynbenze } \\
\text { Decane }\end{array}$ & Liver & [129] \\
\hline
\end{tabular}

alternatives with accessible biomarkers being the forefront candidates for such approaches [130]. Accessible biomarkers can either be membrane bound proteins or found in the extracellular matrix (ECM) of the tumor microenvironment. Ideally, a clinically relevant accessible biomarker should be only expressed in the tumor and not present in normal tissues. In this regard, the specific delivery of bioactive compounds or ligands coupled to cytotoxic drugs to the tumor site will enable effective inhibition of malignant cells with minimal toxic side effects.

Accessible biomarkers can also have diagnostic and prognostic value. Affinity ligands created against suitable targets can be coupled with imaging reagents (fluorescent dyes, radioisotopes, nanoparticles, among others), enabling disease profiling or monitoring of the biodistribution and therapeutic efficacy of a particular cytotoxic agent. Some notable examples include molecular imaging of HER2-positive breast cancers with radioconjugates such as ${ }^{89} \mathrm{Zr}$-trastuzumab $[131,132]$ or radiolabeled affibody molecules [133-135] for positron emission tomography (PET) imaging. Immunofluorescent labeling of membrane-bound HER 2 with quantum dot fluorescent probes for cellular imaging modalities has also been described [136]. Targeting abundant ECM proteins is another means to bring engineered compounds in close proximity to tumor cells. For instance, various isoforms of fibronectin (FN) have been described as valid targets in the delivery of toxic compounds to the tumor microenvironment. L19, a monoclonal antibody directed towards extra domain B of FN, has demonstrated successful tumor targeting ability and biodistribution in preclinical and clinical studies [137]. In addition, a number of L19 derivatives have been developed in the preclinical setting, including conjugates to fluorophores, liposomes, cytokines, and enzymes [138]. In similar fashion, G11, a monoclonal antibody directed against domain $\mathrm{C}$ of the stromal-derived tenascin $\mathrm{C}$, has also been described as a potential targeting component for the selective delivery of therapeutic and imaging agents [139].

\section{Innovative approaches for cancer biomarker discovery}

The development of innovative and high-throughput techniques in recent years has led to rapid proliferation in the identification of potential cancer biomarkers. Since the identification of the first cancer-associated biological signature by pioneering high-throughput technologies such as SAGE [62] and high-capacity microarrays [140], novel and original molecular technologies that interrogate several "omic" subtypes have continued to emerge. Here, we present some of such promising techniques in cancer biomarker discovery.

\subsection{Novel chemical proteomic methodologies for accessible biomarker discovery}

The cancer proteome is a critical component in the pathological mechanisms that underlie malignant disease. Taking the latter into consideration, more recent efforts have directed their focus on integrative proteomic platforms as a valid approach for biomarker discovery. One such approach, chemical proteomics, involves the characterization of candidate proteins either through compound-centric chemical proteomics (CCCP) or activity-based probe profiling (ABPP). The compound-centric approach focuses on the mechanism of action of a known bioactive compound, while the activity-based approach centers on the enzymatic activity of the candidate protein [141]. A number of excellent reviews have discussed the CCCP strategy in detail [142-144]. In this section, we highlight some innovative and promising ABPP chemical proteomic techniques.

The ABPP methodology enables the detection of proteins via covalent modification of an exposed side residue with a chemical reagent such as biotin. It is important to note that this described approach can particularly be exploited in the labeling of accessible biomarkers present in tumor vasculature in situ. As a direct consequence, the labeling of these accessible biomarkers ensures the target proteins retain their native form and structural integrity [145]. To this end, and as a means to screen for candidate accessible markers, our group and others have developed an original ex vivo biotinylation methodology consisting of target protein labeling within intact biological specimens followed by purification and recovery on a streptavidin resin [146, 147]. The described ex vivo chemical proteomics approach has a number of advantages: (1) it is sensitive and easy to implement, (2) it enables the reduction 
of sample complexity prior to subsequent proteomic processing, (3) a large number of accessible proteins can be identified using comparative proteomic methodologies such as mass spectrometry, (4) the choice of biotin as a protein tag enables easy purification even in the presence of heavy anionic surfactants (such as sodium dodecyl sulfate (SDS)), and (5) the cancer-associated proteins identified with this method have been demonstrated to be viable targets for anti-cancer therapeutic strategies[148-150].

\subsubsection{Ex vivo biotinylation of tissue}

Ex vivo biotinylation of accessible proteins present in biopsy tissue involves treatment with a reactive ester derivative of biotin that penetrates tissue via the extracellular space of the tumor lesion. This approach has been demonstrated by our group and others to facilitate the identification of extracellular matrix (ECM) and membrane-bound proteins in primary cancers of the breast [148], pancreas [151], kidney [146], and colon [152], as well as secondary cancers of the liver [153]. In breast cancer, biotinylation of biopsy tissue identified, versican, a large secreted proteoglycan as a potential candidate for targeted anti-cancer therapy [148]. Moreover, our results from biotinylation and comprehensive proteomic analysis of a large collection of pancreatic ductal adenocarcinoma (PDAC) tissue identified transforming growth factor beta-induced protein (TGFBI), latent growth factor beta binding 2 (LTBP2) and asporin, as relevant proteins in the clinical management of PDAC [151]. Following ex vivo perfusion and biotinylation of colorectal cancer (CRC) tissue, we also identified two potential clinically relevant targets, NGAL and GW112 [152]. As a point of interest, we and others have also demonstrated the potential clinical applicability of the ex vivo method in biomarker discovery through perfusion and biotinylation of tumor-bearing murine models of kidney cancer [146] and lymphoma [154]. Indeed, these investigations resulted in the identification of several novel tumor-specific biomarkers [146], further providing a basis for the translation of this method in human kidney tumors (see Section 3.1.2 below).

Chemically modified biotin labels accessible proteins through their primary amine group [148]. However, a number of accessible proteins do not bear these amine groups and will not be recovered by biotinylation. Considering the fact that a large number of accessible proteins are glycosylated [155], our group has also developed a methodology that comprehensively captures (1) biotinylated proteins, (2) glycoproteins, or (3) neither ("rest-fraction") in three sequential steps [150]. Whereas our original biotinylation methodology employed the use of NHS-biotin as a biotinylation reagent, the reagent of choice for the latter described methodology is sulfo-NHSbiotin. The use of sulfo-NHS-biotin has several advantages due to the presence of a sulfonate group, including increased solubility in water leading to better detection of biotinylated peptides. The use of sulfo-NSH-biotin also enables direct alkylation after streptavidin-based affinity purification and overcomes the bottleneck of sample contamination by tryptic streptavidin peptides [145]. Importantly, for the glycopeptide capture step, our approach makes use of a previously described hydrazide-based extraction method [156, 157]. We have also demonstrated that the "rest-fraction" group of proteins also contains a large number of relevant accessible biomarkers, thus enabling the potential discovery of clinically relevant markers and establishing this step as an important part of our methodology [150]. In addition to our described approach employing a minimal amount of already scarce tumoral material, protein quantification is also accurate and reproducible due to the use of several internal standards. We have validated this specific technique in breast cancer tissue, providing important data on 93 differentially modulated proteins some of which have never been described to be associated with breast cancer pathogenesis [150]. Of these novel biomarkers, CD276, a membrane-bound glycoprotein, was demonstrated to be differentially expressed in the examined breast cancer lesions [150].

\subsubsection{Ex vivo biotinylation of organ specimens}

Based on the promising data obtained from the ex vivo perfusion and biotinylation of tumor-bearing mice [146], we initiated a proof-of-principle study to examine the presence of accessible and abundant antigens in surgically resected human kidneys with clear cell carcinoma [149]. Following nephrectomy, ex vivo perfusion and biotinylation was performed on the kidney specimens $(n=3)$, resulting in selective labeling of the vascular portions of the tumor. Our method resulted in the identification of a large number of kidney tumor markers (184 tumor-specific proteins were identified from a total of 637 investigated proteins). Candidate biomarkers included periostin, versican, integrin- $\alpha 1$, thrombospondin-2, fibromodulin, and fibronectin. In addition, based on their expression profile in the tumor microenvironment (epithelia vs. stroma), this method has also enabled the classification of these protein targets for potential ligand-based targeting approaches [149]. Overall, our approach is applicable for biomarker discovery and validation in other surgically resected human organ and tissue types. Further investigations are thus warranted.

\subsection{Profiling of the cancer secretome}

Tumor interstitial fluid (TIF), a liquid phase that accumulates in the tumor interstitium, is an often ignored component of the tumor microenvironment. TIFs, also known as the cancer secretome, represent a valuable source for potential biomarkers. In recent years, proteomic profiling of cancer secretomes has enhanced the identification of novel candidate protein-based biomarkers in a variety of tumor types 
[158-163]. The collection of the cancer secretome can be performed directly at the disease site or ex vivo on biopsy tissue. The in vivo collection of secretomes is possible through the use of microdialysis devices [164] or through capillary ultrafiltration probes $[165,166]$. The first is a widely used technique in neuroscience; however, it works preferentially for small peptides that can easily traverse the dialysis membrane. The latter has been developed to capture larger proteins. Both techniques comprise of the insertion of a device at tumor site, which renders these approaches not always applicable for human cancers. Alternatively, the cancer secretome can be collected ex vivo on freshly excised biopsies. For this purpose, two methods are available: the first utilizes tissue centrifugation at low G-force and the second relies on the passive elution of proteins from the tissue. The centrifugation-based method was originally developed on experimental animals [167] and sequentially employed in humans for ovarian carcinomas [168]. The main disadvantage of this method is the low yield of secretome obtained. Isolation of cancer secretome based on the passive elution technique has been optimized on breast cancer biopsies by Celis and collaborators [158]. The method consists of incubating a small piece of a fresh biopsy in buffered saline phosphate (PBS) or serum-free medium during a period of time varying from 1 to $24 \mathrm{~h}$ at $37{ }^{\circ} \mathrm{C}$, in a $\mathrm{CO}_{2}$ humidified incubator. The fluid, corresponding to the cancer secretome, is then collected and prepared for proteomic analysis. This approach has been employed by many researcher groups and applied to mouse and human tissue for biomarker discovery efforts in renal cell carcinoma [163], hepatocellular carcinoma, ovarian cancer [169], and colorectal cancer [159]. Several proteins have been presented as potential biomarkers (Table 3), but none of them has been broadly validated to satisfy the criteria required for clinical application. Interestingly, this approach has been evaluated for the identification of early diagnostic biomarkers for CRC on mice that develop spontaneous [159] or chemically induced [172] tumors.

\subsection{Identification of candidate biomarkers}

Following recovery and purification, biotinylated or captured proteins can be further processed by high-throughput identification and validation methods. In the following section, we briefly discuss currently established approaches in the identification and evaluation of clinically relevant biomarkers and targets.

\subsubsection{Bioinformatics methods}

The identification of candidate cancer biomarkers has advanced through the use of bioinformatics tools that enable the analysis of large datasets containing a vast amount of information derived from diverse studies. A database screening approach (UniGene/EST) that employs a highly stringent
BLAST algorithm against an expressed sequence tag of a target protein is among the earliest described bioinformatics tools used to identify potential biomarkers [173]. In this perspective, Huminiecki and colleagues identified four novel endothelial cell-specific genes (ECSM 1-3 and magic roundabout) using the UniGene/EST approach combined with SAGE and RT-PCR [173]. In addition, groups of proteins can also be examined and identified using the publicly accessible STRING program [174]. The rationale behind STRING analysis is to screen and identify the most relevant biological clusters of accessible cancer biomarkers. In addition, modulated proteins can be connected according to their biological expression, regulation, and function [174].

Bioinformatics processing of mass spectrometry data can occur with various software tools that have been developed to support data collection and data analysis. Such bioinformatics tools include DeepQuanTR which enables pairwise comparison of the average normalized signal intensities for multiple peptides corresponding to the same protein in a number of tissue samples [175]. In addition, state-of-the-art comparative proteomic analysis typically requires a large sample number to establish proofof-principle, which cannot be achieved with conventional proteomic strategies such as exogenous isotopic labeling. To eliminate this obstacle, DeepQuanTR has been designed to have no limit in sample number analysis, enabling the processing of a significant number of samples for large-scale proteomic projects [175]. The DeepQuanTR approach has been applied for protein identification in the previously described ex vivo biotinylation procedure for surgically resected human kidney tumors $(n=$ 637), where two ECM-derived (fibronectin and tenascin) were identified as relevant for this malignancy [149]. DeepQuanTR was also employed for the comparative proteomic analysis of three syngeneic murine models of liver metastasis using an in vivo biotinylation approach [153]. The analysis led to the identification of 12 disease-specific proteins, further validated by immunofluorescence and in vivo tumor targeting with radiolabeled antibodies. It is important to note that DeepQuanTR analysis not only retroactively identifies proteins through alignment algorithms, but also identifies differentially regulated protein splice variants [175].

\subsubsection{Verification and validation of candidate biomarkers}

Following their identification, potential biomarkers undergo pre-validation via high-throughput verification methodologies. Moreover, before moving through to the validation stage, it is essential that candidate biomarkers are also verified using stringent guidelines as well as a large number of samples to avoid "false-positives". Differentially expressed proteins can ideally be verified by immunohistochemistry (IHC), fluorescence in situ hybridization (FISH), RNA in situ hybridization or other in situ molecular techniques on tissue microarrays (TMAs) $[176,177]$. The TMA methodology enables the simultaneous 
Table 3 Cancer secretomederived biomarkers

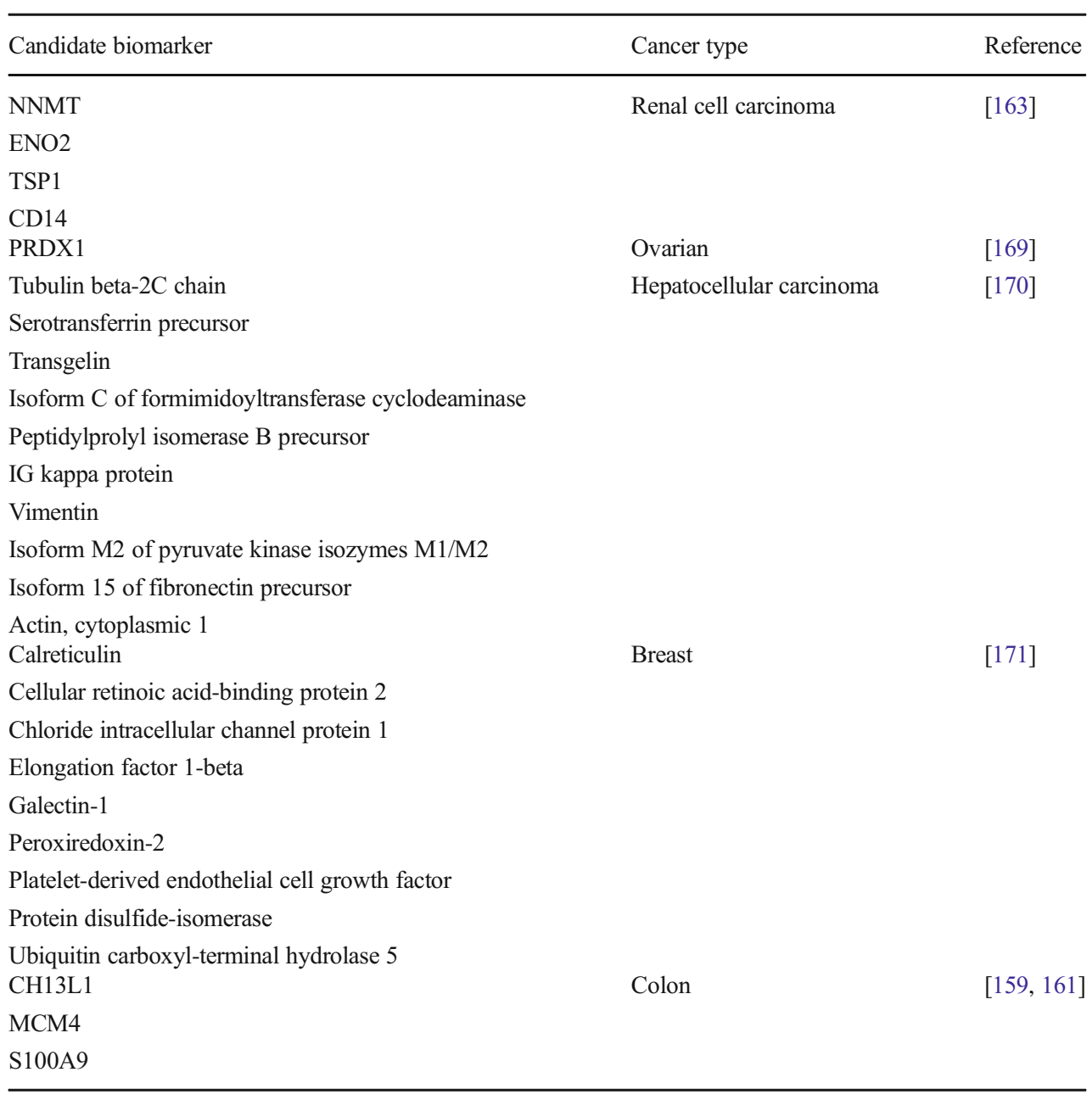

detection of multiple specimens by comparing normal and tumoral tissue specimens as a means to unravel the clinical relevance of the biomarker candidate. Interestingly, other investigators have also adapted the TMA methodology to include frozen tissue [178] and needle biopsies [179].

More recent verification approaches include targeted methods such as multiple reaction monitoring (MRM) or MRM coupled to stable isotope standard with capture by anti-peptide antibodies (SISCAPA) [180, 181]. MRM is a quantitative method utilized to screen for a large number of candidate biomarkers. In addition, this approach has excellent multiplexing capabilities and is substantially more sensitive and accurate than conventional biomarker discovery tools. The targeted MRM methodology provides absolute structural specificity of the analyte, resulting in increased accuracy of analysis. Moreover, this approach has the advantage of being faster and less expensive than other verification methods due to its high-throughput capabilities and the non-use of antibodies. On the other hand, while conventional TMA approaches have an advantage of using a low amount of formalin fixed tumor specimens; MRM analysis requires high-quality frozen tissue which may have limited availability. However, by employing anti-peptide antibodies to enrich candidate peptides, the SISCAPA approach coupled to MRM provides additional advantages such as increased measurement sensitivity resulting in a significantly enhanced biomarker verification output compared to other conventional methods [182, 183].

Surprisingly, despite its innovation and promise targeted quantitative mass spectrometric analysis is not a widely accepted tool for the validation of candidate biomarkers, as this approach is unable to achieve the accuracy and precision required by regulatory bodies (such as the FDA) for subsequent clinical implementation. As indicated, the validation of biomarker candidates requires the use of reliable antibodies that can quantitatively assess each candidate. Classical methodologies such as ELISA and radioimmunoassay (RIA) are typically employed at this final step of the biomarker discovery pipeline [181].

\subsection{Other innovative methods}

Nanoproteomic technologies such as immuno-PCR (iPCR) for quantitative detection of biomarker antigens [184] and quantum dots for concurrent detection of multiple biomarkers [185] represent emerging methodologies that have 
demonstrated superior sensitivity over classical approaches. In addition, other tissue-specific techniques such as isotopecoded affinity labeling [186], in vivo silica-based mapping of proteins [187], and in vivo peptide display targeting [188] have shown promise in the identification of candidate biomarkers. Quantitative real-time RT-PCR, considered the "gold standard" for quantifying and validating gene expression, can also be performed on a high-throughput scale through the use of microfluidic cards [63, 189].

\section{Challenges in biomarker discovery}

The identification and validation of clinically relevant biomarkers remains one of the major limiting factors in the development of diagnostic, prognostic, and therapeutic modalities. Tumor specimens contain a complex mixture of DNA, RNA, proteins, metabolites, and lipids, which can contribute to challenges in data interpretation and analysis. Candidate biomarkers can also be difficult to validate and may call for different levels of validation depending on their intended use [190]. Tumor heterogeneity within and between individual patients additionally has a profound impact on biomarker development [191]. Likewise, detecting candidate biomarkers with a low expression profile remains a significant challenge.

\subsection{Biomarker source material}

In malignant disease, the principal sources of biological material available for biomarker discovery are tissue and blood. The analysis of tumor tissue enables the study of its microenvironment. However, the complexity associated with cellular heterogeneity can create a hindrance in this investigation. Tumor tissue contains a diverse mixture of stromal fibroblasts, endothelial cells, epithelial cells, and malignant cells. In addition, modifications at the transcriptional and post-transcriptional level of analytes present in the tumor microenvironment can lead to the presence of diverse heterogenous polypeptide species within an individual tumor. While laser capture microdissection (LCM) can circumvent the problem of cellular heterogeneity by capturing a histologically pure subpopulation of cells for analysis [192], a major limitation with this approach is the low amount of biomolecules (DNA, RNA, or protein) recovered. For mass spectrometric analysis, biomarker discovery typically requires a substantial amount of starting material from $10^{4}$ to $10^{5}$ range in tumoral cells [193, 194], while for oncogenomic analysis, $10^{3}$ to $10^{7}$ cells are typically required [195]. In clinical practice, on the other hand, blood is the most frequently used biological fluid for biomarker evaluation. Although blood can be obtained through a less invasive process compared to a tissue biopsy, the use of blood as a biomarker source material remains challenging due to the low abundance of target material. It is well known that the human plasma proteome has a dynamic range of over 12 orders of magnitude with $99 \%$ of the protein mass represented by 22 proteins $[196,197]$. For example, albumin, the most abundant protein present in plasma, represents approximately $50 \%$ of the total protein concentration [198]. As a direct consequence, relevant biomarkers that are already heavily diluted in blood circulation are masked by the huge number of these ubiquitously distributed proteins of no clinical significance. Since there is presently no established proteomic platform that can quantitatively analyze a dynamic range of up to $10^{12}$ [196], it is required that high-abundance plasma proteins are removed prior to analysis [199, 200]. The removal of high-abundance proteins can, however, increase the risk of losing important biological information, as low abundance candidate biomarkers can also be co-depleted during this process [201].

The procurement of valuable human tissue for research banking is also an important practice in the field of biomarker discovery. However, standard guidelines require that procured biopsy tissue be primarily disbursed for clinical purposes, and the remaining scarce tissue donated for research intent after thorough clinical expenditure [202]. Thus, in the research setting, biomarker profiling with tumor tissue is further limited by the small amount of sample available. For their potential use, the banked tumor specimens are formalin fixed and embedded in paraffin for IHC or flash frozen and embedded in optimal cutting temperature compound (OCT) for the purpose of obtaining histologically frozen sections. Nonetheless, due to a frequent lack of adequate handling and preservation procedures, an additional concern among researchers is the poor sample quality in a substantial proportion of the available tissue specimens [203]. A lack of adherence of standard operating guidelines in collecting, processing, storing, and annotating these biological specimens in some research facilities has also prompted a number of researcher to question the validity and reliability of their data [203]. In this context, standardized biological repositories, where good laboratory practice, transparency, accountability, and ethics are guaranteed, are currently established platforms in the research sphere.

\subsubsection{Tumor heterogeneity}

As discussed previously, the burden of heterogeneity in solid tumors presents an obstacle in biomarker discovery. Breast cancer, for instance, has many diverse molecular subtypes including luminal A and B, basal-like, HER2+ and ER+. Thus, due to the recognized challenges linked to tumor heterogeneity, the concept that one biomarker can be a sole disease predictor for all patients may need to be replaced by the paradigm that each patient subset possesses its own set of unique biomarkers. This by extension will have an impact on the manner in which biomarker discovery studies are designed and executed. One important aspect that needs to be 
taken into consideration is that currently employed statistical methodologies in biomarker discovery are designed for homogeneous disease. This could largely explain the low success rate attributed to the clinical translation of candidate biomarkers. Using Monte Carlo simulation [204], Wallstrom and colleagues demonstrate that larger sample size is required for candidate biomarker selection for heterogeneous disease compared to homogenous disease [205]. In addition, the authors also revealed that the two disease models require different statistical tests for adequate selection and analysis. For heterogenous populations, the use of non-parametric statistical tests such as PAUC were deemed appropriate for improved efficiency in candidate biomarker assessment [205].

Spatial heterogeneity, a fundamental biological feature of the tumor microenvironment [206], can also add an additional level of complexity to biomarker discovery and development. Regional differences within a solid tumor (e.g., oxygen availability) can exert differing selective pressure on distinct regions of the tumor giving rise to a wide variety of dominant subclones. As they evolve over time, such heterogenous subclones can have a direct impact on clinical presentation and treatment response. Moreover, spatial differences within the tumor can also contribute to potential sampling bias in biopsy specimens, limiting the ability to adequately identify, validate, and reproduce relevant biomarkers. Since cancer drivers may vary over the course of the disease, there is therefore a pressing need to identify potential biomarkers in the context of tumor spatial heterogeneity. While, in reality, this may be difficult to execute, some recent biomarker-driven studies including BATTLE-2 (NCT01248247) and LungMAP (NCT02154490) are identifying predictive biomarkers based on tumor profiling over the clinical course of the disease. In addition, the recently initiated TRACERx study (NCT01888601), in which multiregional and longitudinal tumor sampling is performed from diagnosis to relapse has important implications for biomarker-based precision medicine [207]. Importantly, the DARWIN II trial (NCT02183883) may also help determine the impact of subclonal cancer drivers on anti-tumor response and resistance to therapy through extensive biomarker analysis of genomic and immune markers.

\subsection{Biomarker discovery in preclinical animal models}

The use of genetically engineered animal models that can recapitulate distinct features of human cancers is an established paradigm in biomarker discovery and preclinical drug testing [208, 209]. As previously highlighted, identifying biomarkers derived from blood has been so far limited by the fundamental complexity and variability of the human plasma proteome [197]. Due to the absence of environmental and genetic variability in isogenic strains of tumor-bearing mice, evaluating plasma derived from such models can be vital in accelerating the biomarker pipeline from the identification, verification, and validation of cancer-specific markers [210, 211]. Despite their promise, however, many preclinical animal models are unable to accurately predict the clinical efficacy of a novel biomarker or cancer agent due to their inability to reflect the complexity and spatial heterogeneity of a human tumor. Thus, in an effort to improve clinical applicability, patient-derived tumor xenograft (PDTX) models that parallel the genetic and phenotypic heterogeneity of a human tumor have been developed [212]. PDTX involves the implantation of surgically resected primary tumor specimens onto an immunocompromised mouse, and as such represent a rich resource for predictive biomarker [213] and drug development studies [214]. Consequent proof-of-principle studies for patients with high-grade ovarian cancers [215] and other advanced cancers [216] have shown the clinical potential of these PDTX in vivo surrogates. Notwithstanding, directly extrapolating data obtained from PDTX models remains a difficulty due to their poor predictive value. The reasons for these perceived challenges are multifactorial, but one key shortcoming is that PDTX models cannot fully capture the human immune system, a critical component of the tumor microenvironment [217]. To this end, the development of humanized PDTX models that can recapitulate the human immune system is currently an active area of research [218, 219].

\subsection{Limitations of current techniques}

Although the innovative methodologies described in this review provide a number of technical benefits over classical biomarker discovery approaches, several limitations ascribed to their use still exist. For instance, the presented ex vivo biotinylation approaches are biased towards abundant and accessible antigens. Less-abundant or intracellular proteins will therefore not comprise the repertoire of recovered biomarker candidates using these approaches. For blood-based samples, this perceived bias presents a number of challenges due to the presence of irrelevant high-abundance plasma proteins. As discussed earlier, immunodepletion of these high-abundant proteins can lead to the enrichment of lower abundance proteins, thereby increasing detection sensitivity of relevant peptides. However, a potential hurdle with the immunodepletion approach is that lower abundance proteins can also be removed alongside the targeted proteins. Consistent with this observation, a preclinical study has shown that lowabundance proteins derived from human plasma account for only 5-6\% of identified proteins after shotgun proteomic analysis [220]. To further confound this issue, it has also been reported that shotgun proteomic analysis of complex mixtures yields information for only a fraction of relevant peptides after a single analytical run. This has a significant impact on the profiling of potential biomarkers, as the presence or absence of a particular protein may be the result of "analytical 
incompleteness" and not real differences between examined samples [221]. A statistically relevant amount of replicates $(n=10)$ is therefore required when performing comparative proteomic analysis using mass spectrometric methodologies.

\section{Conclusions}

The greatest unmet clinical need in biomarker discovery is the implementation of early detection to aid clinical decisionmaking, thereby improving risk stratification and clinical outcome. The current state-of-the-art with regard to biomarker discovery and development remains expression profiling by high-throughput sequencing and mass spectrometric-based approaches. It is, however, important to mention that the emerging ex vivo chemical proteomic technology also add further enhancement to the field of biomarker discovery by specifically detecting accessible biomarkers. Taken together, the described technological advances are therefore critical in furthering our understanding of tumor biology and disease progression in both the preclinical and clinical setting. However, due to the complex molecular architecture associated with biomolecules, these approaches are still yet to attain the sensitivity and specificity required to confer cancer biomarkers as standard clinical tools. Indeed, a key consideration for the innovative approaches described in this review is the wide dynamic range of analytes present in biological samples. A major objective for clinical translation therefore involves reduction of the dynamic range in analyzed samples as a means to unveil important biomarkers that are present in low abundance. This can directly have an impact on reproducibility and statistical modeling. Improved fractionation, isolation, and enrichment strategies therefore need to be developed to tackle the issue of dynamic range. Novel approaches using equalizer beads [222] and enzyme-specific labels [223] may further reduce dynamic range and aid in the identification of less-abundant analytes.

The burden of tumor heterogeneity increases the complexity of precision medicine-driven biomarker discovery efforts. While taking multiple tumor biopsies as a means to determine the exact clonal composition of tumors may not be a simple or easy task, it can potentially improve our understanding of tumor evolution during disease progression and therapy. As an adaptation, longitudinal studies involving both tissue and liquid biopsies could enable more effective prediction of the disease course and may also be beneficial in monitoring treatment response. Developing and improving non-invasive modalities may thus be a more realistic approach in interrogating tumor heterogeneity in clinical practice [224]. Further to this, the use of biomarkers with predictive, diagnostic, and prognostic value is also a direct prerequisite for improved cancer treatment and management. When evaluating candidate biomarkers, it is important to consider that analytical artifacts may be falsely grouped as candidate markers. Robust validation of disease-specific biomarkers can only be achieved through strict implementation of proper experimental design and study execution. Intensive standardization is also required to guarantee the reliability, reproducibility, and comparability of identified biomarker candidates. Although translating the latter into practice may be a current challenge, the era of reliable biomarkers that will ultimately guide and improve patient care may not be too distant in our future.

\section{Compliance with ethical standards}

Conflict of interest The authors declare that they have no conflicts of interest.

\section{References}

1. Ragnhammar, P., Hafstrom, L., Nygren, P., \& Glimelius, B. (2001). A systematic overview of chemotherapy effects in colorectal cancer. [Review]. Acta Oncologica, 40(2-3), 282-308.

2. Balar, A. V., \& Milowsky, M. I. (2015). Cytotoxic and DNAtargeted therapy in urothelial cancer: have we squeezed the lemon enough? [Review]. Cancer, 121(2), 179-187. https://doi.org/10. 1002/cncr.28754.

3. Ludwig, J. A., \& Weinstein, J. N. (2005). Biomarkers in cancer staging, prognosis and treatment selection. [Research Support, N.I.H., Extramural. Research Support, N.I.H., Intramural. Research Support, Non-U.S. Gov't. Review]. Nature Reviews. Cancer, 5(11), 845-856. https://doi.org/10.1038/nrc1739.

4. Drucker, E., \& Krapfenbauer, K. (2013). Pitfalls and limitations in translation from biomarker discovery to clinical utility in predictive and personalised medicine. The EPMA Journal, 4(1), 7. https://doi.org/10.1186/1878-5085-4-7.

5. Panneerselvam, J., Xie, G., Che, R., Su, M., Zhang, J., Jia, W., et al. (2016). Distinct metabolic signature of human bladder cancer cells carrying an impaired fanconi anemia tumor-suppressor signaling pathway. [Research Support, N.I.H., Extramural]. Journal of Proteome Research, 15(4), 1333-1341. https://doi.org/10.1021/ acs.jproteome.6b00076.

6. Halama, A., Guerrouahen, B. S., Pasquier, J., Diboun, I., Karoly, E. D., Suhre, K., et al. (2015). Metabolic signatures differentiate ovarian from colon cancer cell lines. [Research Support, Non-U.S. Gov't]. Journal of Translational Medicine, 13, 223. https://doi. org/10.1186/s12967-015-0576-z.

7. Zhang, A., Sun, H., Yan, G., Wang, P., \& Wang, X. (2015, 2015). Metabolomics for biomarker discovery: moving to the clinic. [Research Support, Non-U.S. Gov't. Review]. BioMed Research International, 354671. https://doi.org/10.1155/2015/354671.

8. Mal, M. (2016). Noninvasive metabolic profiling for painless diagnosis of human diseases and disorders. [Review]. Future Science OA, 2(2), FSO106. https://doi.org/10.4155/fsoa-20150014.

9. Louis, E., Adriaensens, P., Guedens, W., Bigirumurame, T., Baeten, K., Vanhove, K., et al. (2016). Detection of lung cancer through metabolic changes measured in blood plasma. Journal of Thoracic Oncology, 11(4), 516-523. https://doi.org/10.1016/j. jtho.2016.01.011.

10. Gold, P., \& Freedman, S. O. (1965). Demonstration of tumorspecific antigens in human colonic carcinomata by immunological tolerance and absorption techniques. The Journal of Experimental Medicine, 121, 439-462. 
11. Chatterjee, S. K., \& Zetter, B. R. (2005). Cancer biomarkers: knowing the present and predicting the future. [Review]. Future Oncology, 1(1), 37-50. https://doi.org/10.1517/14796694.1.1.37.

12. Tanaka, T., Tanaka, M., \& Ishigamori, R. (2010). Biomarkers for colorectal cancer. [Research Support, Non-U.S. Gov't Review]. International Journal of Molecular Sciences, 11(9), 3209-3225. https://doi.org/10.3390/ijms11093209.

13. Grunnet, M., \& Sorensen, J. B. (2012). Carcinoembryonic antigen (CEA) as tumor marker in lung cancer. [Review]. Lung Cancer, 76(2), 138-143. https://doi.org/10.1016/j.lungcan.2011.11.012.

14. Jakupciak, J. P., Wang, W., Markowitz, M. E., Ally, D., Coble, M., Srivastava, S., et al. (2005). Mitochondrial DNA as a cancer biomarker. [Comparative Study Research Support, N.I.H., Extramural Research Support, U.S. Gov't, P.H.S.] The Journal of Molecular Diagnostics, 7(2), 258-267. https://doi.org/10. 1016/S1525-1578(10)60553-3.

15. Cai, F. F., Kohler, C., Zhang, B., Chen, W. J., Barekati, Z., Garritsen, H. S., et al. (2011). Mutations of mitochondrial DNA as potential biomarkers in breast cancer. [Research Support, NonU.S. Gov't]. Anticancer Research, 31(12), 4267-4271.

16. Vincent, M. D., Kuruvilla, M. S., Leighl, N. B., \& Kamel-Reid, S. (2012). Biomarkers that currently affect clinical practice: EGFR, ALK, MET, KRAS. Current Oncology, 19(Suppl 1), S33-S44. https://doi.org/10.3747/co.19.1149.

17. Punt, C. J., Koopman, M., \& Vermeulen, L. (2016). From tumour heterogeneity to advances in precision treatment of colorectal cancer. [Review]. Nature Reviews. Clinical Oncology. https://doi.org/ 10.1038/nrclinonc.2016.171.

18. Sharma, S. V., Bell, D. W., Settleman, J., \& Haber, D. A. (2007). Epidermal growth factor receptor mutations in lung cancer. Nature Reviews. Cancer, 7(3), 169-181. https://doi.org/10.1038/nrc2088.

19. Arrington, A. K., Heinrich, E. L., Lee, W., Duldulao, M., Patel, S., Sanchez, J., et al. (2012). Prognostic and predictive roles of KRAS mutation in colorectal cancer. [Review]. International Journal of Molecular Sciences, 13(10), 12153-12168. https://doi.org/10. 3390/ijms131012153.

20. Tomasini, P., Serdjebi, C., Khobta, N., Metellus, P., Ouafik, L., Nanni, I., et al. (2016). EGFR and KRAS mutations predict the incidence and outcome of brain metastases in non-small cell lung cancer. International Journal of Molecular Sciences, 17(12). https://doi.org/10.3390/ijms17122132.

21. Lohinai, Z., Klikovits, T., Moldvay, J., Ostoros, G., Raso, E., Timar, J., et al. (2017). KRAS-mutation incidence and prognostic value are metastatic site-specific in lung adenocarcinoma: poor prognosis in patients with KRAS mutation and bone metastasis. Scientific Reports, 7, 39721. https://doi.org/10.1038/srep39721.

22. Ma, C., Wei, S., \& Song, Y. (2011). T790M and acquired resistance of EGFR TKI: a literature review of clinical reports. Journal of Thoracic Disease, 3(1), 10-18. https://doi.org/10.3978/j.issn. 2072-1439.2010.12.02.

23. Hollstein, M., Sidransky, D., Vogelstein, B., \& Harris, C. C. (1991). p53 mutations in human cancers. [Comparative Study Research Support, U.S. Gov't, P.H.S. Review]. Science, 253(5015), 49-53.

24. Moller, M. B., Gerdes, A. M., Skjodt, K., Mortensen, L. S., \& Pedersen, N. T. (1999). Disrupted p53 function as predictor of treatment failure and poor prognosis in B- and T-cell nonHodgkin's lymphoma. [Comparative Study Research Support, Non-U.S. Gov't]. Clinical Cancer Research, 5(5), 1085-1091.

25. Siddik, Z. H. (2003). Cisplatin: mode of cytotoxic action and molecular basis of resistance. [Research Support, U.S. Gov't, Non-P.H.S. Research Support, U.S. Gov't, P.H.S. Review]. Oncogene, 22(47), 7265-7279. https://doi.org/10.1038/sj.onc. 1206933.

26. Paek, A. L., Liu, J. C., Loewer, A., Forrester, W. C., \& Lahav, G. (2016). Cell-to-cell variation in p53 dynamics leads to fractional killing. [Research Support, N.I.H., Extramural Research Support, Non-U.S. Gov't]. Cell, 165(3), 631-642. https://doi.org/10.1016/ j.cell.2016.03.025.

27. Zhao, R., Choi, B. Y., Lee, M. H., Bode, A. M., \& Dong, Z. (2016). Implications of genetic and epigenetic alterations of CDKN2A (p16(INK4a)) in cancer. [Review]. eBioMedicine, 8, 30-39. https://doi.org/10.1016/j.ebiom.2016.04.017.

28. Zhao, J., Zhang, Z., Liao, Y., \& Du, W. (2014). Mutation of the retinoblastoma tumor suppressor gene sensitizes cancers to mitotic inhibitor induced cell death. American Journal of Cancer Research, 4(1), 42-52.

29. Theriault, B. L., Dimaras, H., Gallie, B. L., \& Corson, T. W. (2014). The genomic landscape of retinoblastoma: a review. [Research Support, N.I.H., Extramural Research Support, NonU.S. Gov't Review]. Clinical and Experimental Ophthalmology, 42(1), 33-52. https://doi.org/10.1111/ceo.12132.

30. Sonnenblick, A., de Azambuja, E., Azim Jr., H. A., \& Piccart, M. (2015). An update on PARP inhibitors-moving to the adjuvant setting. [Review]. Nature Reviews. Clinical Oncology, 12(1), 27-41. https://doi.org/10.1038/nrclinonc.2014.163.

31. Ledermann, J. A. (2016). PARP inhibitors in ovarian cancer. Annals of Oncology, 27(Suppl 1), i40-i44. https://doi.org/10. 1093/annonc/mdw094.

32. Dawson, M. A., \& Kouzarides, T. (2012). Cancer epigenetics: from mechanism to therapy. Cell, $150(1), 12-27$. https://doi.org/ 10.1016/j.cell.2012.06.013.

33. Ashktorab, H., Rahi, H., Wansley, D., Varma, S., Shokrani, B., Lee, E., et al. (2013). Toward a comprehensive and systematic methylome signature in colorectal cancers. Epigenetics, 8(8), 807-815. https://doi.org/10.4161/epi.25497.

34. Szmida, E., Karpinski, P., Leszczynski, P., Sedziak, T., Kielan, W., Ostasiewicz, P., et al. (2015). Aberrant methylation of ERBB pathway genes in sporadic colorectal cancer. Journal of Applied Genetics, 56(2), 185-192. https://doi.org/10.1007/s13353-0140253-6.

35. Warren, J. D., Xiong, W., Bunker, A. M., Vaughn, C. P., Furtado, L. V., Roberts, W. L., et al. (2011). Septin 9 methylated DNA is a sensitive and specific blood test for colorectal cancer. BMC Medicine, 9, 133. https://doi.org/10.1186/1741-7015-9-133.

36. Boland, C. R., \& Goel, A. (2010). Microsatellite instability in colorectal cancer. Gastroenterology, 138(6), 2073-2087 e2073. https://doi.org/10.1053/j.gastro.2009.12.064.

37. Herceg, Z., \& Hainaut, P. (2007). Genetic and epigenetic alterations as biomarkers for cancer detection, diagnosis and prognosis. [Review]. Molecular Oncology, 1(1), 26-41. https://doi.org/ 10.1016/j.molonc.2007.01.004.

38. Gatalica, Z., Vranic, S., Xiu, J., Swensen, J., \& Reddy, S. (2016). High microsatellite instability (MSI-H) colorectal carcinoma: a brief review of predictive biomarkers in the era of personalized medicine. Familial Cancer, 15(3), 405-412. https://doi.org/10. 1007/s10689-016-9884-6.

39. Des Guetz, G., Schischmanoff, O., Nicolas, P., Perret, G. Y., Morere, J. F., \& Uzzan, B. (2009). Does microsatellite instability predict the efficacy of adjuvant chemotherapy in colorectal cancer? A systematic review with meta-analysis. [Meta-Analysis Review]. European Journal of Cancer, 45(10), 1890-1896. https://doi.org/10.1016/j.ejca.2009.04.018.

40. Ribic, C. M., Sargent, D. J., Moore, M. J., Thibodeau, S. N., French, A. J., Goldberg, R. M., et al. (2003). Tumor microsatellite-instability status as a predictor of benefit from fluorouracil-based adjuvant chemotherapy for colon cancer. [Clinical Trial Randomized Controlled Trial Research Support, Non-U.S. Gov't Research Support, U.S. Gov't, P.H.S.] The New England Journal of Medicine, 349(3), 247-257. https://doi.org/ 10.1056/NEJMoa022289. 
41. Koopman, M., Venderbosch, S., van Tinteren, H., Ligtenberg, M. J., Nagtegaal, I., Van Krieken, J. H., et al. (2009). Predictive and prognostic markers for the outcome of chemotherapy in advanced colorectal cancer, a retrospective analysis of the phase III randomised CAIRO study. European Journal of Cancer, 45(11), 1999-2006. https://doi.org/10.1016/j.ejca.2009.04.017.

42. Devaud, N., \& Gallinger, S. (2013). Chemotherapy of MMRdeficient colorectal cancer. [Review]. Familial Cancer, 12(2), 301-306. https://doi.org/10.1007/s10689-013-9633-z.

43. Hause, R. J., Pritchard, C. C., Shendure, J., \& Salipante, S. J. (2016). Classification and characterization of microsatellite instability across 18 cancer types. Nature Medicine, 22(11), 13421350. https://doi.org/10.1038/nm.4191.

44. Jeronimo, C., Usadel, H., Henrique, R., Oliveira, J., Lopes, C., Nelson, W. G., et al. (2001). Quantitation of GSTP1 methylation in non-neoplastic prostatic tissue and organ-confined prostate adenocarcinoma. [Research Support, Non-U.S. Gov't Research Support, U.S. Gov't, P.H.S.] Journal of the National Cancer Institute, 93(22), 1747-1752.

45. Gonzalgo, M. L., Pavlovich, C. P., Lee, S. M., \& Nelson, W. G. (2003). Prostate cancer detection by GSTP1 methylation analysis of postbiopsy urine specimens. [Research Support, Non-U.S. Gov't Research Support, U.S. Gov't, P.H.S.] Clinical Cancer Research, 9(7), 2673-2677.

46. Rivera, A. L., Pelloski, C. E., Gilbert, M. R., Colman, H., De La Cruz, C., Sulman, E. P., et al. (2010). MGMT promoter methylation is predictive of response to radiotherapy and prognostic in the absence of adjuvant alkylating chemotherapy for glioblastoma. [Research Support, N.I.H., Extramural]. Neuro-Oncology, 12(2), 116-121. https://doi.org/10.1093/neuonc/nop020.

47. Seligson, D. B., Horvath, S., Shi, T., Yu, H., Tze, S., Grunstein, M., et al. (2005). Global histone modification patterns predict risk of prostate cancer recurrence. [Research Support, N.I.H., Extramural Research Support, Non-U.S. Gov't Research Support, U.S. Gov’t, P.H.S.] Nature, 435(7046), 1262-1266. https://doi.org/10.1038/nature03672.

48. Seligson, D. B., Horvath, S., McBrian, M. A., Mah, V., Yu, H., Tze, S., et al. (2009). Global levels of histone modifications predict prognosis in different cancers. [Research Support, N.I.H., Extramural Research Support, Non-U.S. Gov't]. The American Journal of Pathology, 174(5), 1619-1628. https://doi.org/10. 2353/ajpath.2009.080874.

49. Diehl, F., Li, M., Dressman, D., He, Y., Shen, D., Szabo, S., et al. (2005). Detection and quantification of mutations in the plasma of patients with colorectal tumors. [Research Support, N.I.H., Extramural Research Support, Non-U.S. Gov't]. Proceedings of the National Academy of Sciences of the United States of America, 102(45), 16368-16373. https://doi.org/10.1073/pnas. 0507904102.

50. Jahr, S., Hentze, H., Englisch, S., Hardt, D., Fackelmayer, F. O., Hesch, R. D., et al. (2001). DNA fragments in the blood plasma of cancer patients: quantitations and evidence for their origin from apoptotic and necrotic cells. [Research Support, Non-U.S. Gov't]. Cancer Research, 61(4), 1659-1665.

51. Spindler, K. L., Pallisgaard, N., Andersen, R. F., Brandslund, I., \& Jakobsen, A. (2015). Circulating free DNA as biomarker and source for mutation detection in metastatic colorectal cancer. [Clinical Trial, Phase II Research Support, Non-U.S. Gov't]. PLoS One, 10(4), e0108247. https://doi.org/10.1371/journal. pone.0108247.

52. Schwarzenbach, H., \& Pantel, K. (2015). Circulating DNA as biomarker in breast cancer. [Research Support, Non-U.S. Gov't Review]. Breast Cancer Res, 17(1), 136. https://doi.org/10.1186/ s13058-015-0645-5.

53. No, J. H., Kim, K., Park, K. H., \& Kim, Y. B. (2012). Cell-free DNA level as a prognostic biomarker for epithelial ovarian cancer.
[Research Support, Non-U.S. Gov't]. Anticancer Research, 32(8), 3467-3471.

54. Szpechcinski, A., Chorostowska-Wynimko, J., Struniawski, R., Kupis, W., Rudzinski, P., Langfort, R., et al. (2015). Cell-free DNA levels in plasma of patients with non-small-cell lung cancer and inflammatory lung disease. [Evaluation Studies Research Support, Non-U.S. Gov't]. British Journal of Cancer, 113(3), 476-483. https://doi.org/10.1038/bjc.2015.225.

55. Spindler, K. L., Appelt, A. L., Pallisgaard, N., Andersen, R. F., Brandslund, I., \& Jakobsen, A. (2014). Cell-free DNA in healthy individuals, noncancerous disease and strong prognostic value in colorectal cancer. International Journal of Cancer, 135(12), 2984-2991. https://doi.org/10.1002/ijc.28946.

56. Alexandrov, L. B., Nik-Zainal, S., Wedge, D. C., Aparicio, S. A., Behjati, S., Biankin, A. V., et al. (2013). Signatures of mutational processes in human cancer. [Research Support, Non-U.S. Gov't]. Nature, 500(7463), 415-421. https://doi.org/10.1038/ nature 12477.

57. Byron, S. A., Van Keuren-Jensen, K. R., Engelthaler, D. M., Carpten, J. D., \& Craig, D. W. (2016). Translating RNA sequencing into clinical diagnostics: opportunities and challenges. [Research Support, Non-U.S. Gov’t Review]. Nature Reviews. Genetics, 17(5), 257-271. https://doi.org/10.1038/nrg.2016.10.

58. Peng, L., Bian, X. W., Li, D. K., Xu, C., Wang, G. M., Xia, Q. Y., et al. (2015). Large-scale RNA-Seq transcriptome analysis of 4043 cancers and 548 normal tissue controls across 12 TCGA cancer types. [Research Support, Non-U.S. Gov't]. Scientific Reports, 5, 13413. https://doi.org/10.1038/srep13413.

59. Alexandrov, L. B., Nik-Zainal, S., Wedge, D. C., Campbell, P. J., \& Stratton, M. R. (2013). Deciphering signatures of mutational processes operative in human cancer. [Research Support, NonU.S. Gov’t]. Cell Reports, 3(1), 246-259. https://doi.org/10. 1016/j.celrep.2012.12.008.

60. Silveyra, P., Wang, G., \& Floros, J. (2010). Human SP-A1 (SFTPA1) variant-specific 3' UTRs and poly(A) tail differentially affect the in vitro translation of a reporter gene. [Research Support, N.I.H., Extramural]. American Journal of Physiology. Lung Cellular and Molecular Physiology, 299(4), L523-L534. https:// doi.org/10.1152/ajplung.00113.2010.

61. Gray, J. W., \& Collins, C. (2000). Genome changes and gene expression in human solid tumors. [Review]. Carcinogenesis, 21(3), 443-452.

62. Velculescu, V. E., Zhang, L., Vogelstein, B., \& Kinzler, K. W. (1995). Serial analysis of gene expression. [Research Support, Non-U.S. Gov't Research Support, U.S. Gov't, P.H.S.] Science, 270(5235), $484-487$.

63. Peck, D., Crawford, E. D., Ross, K. N., Stegmaier, K., Golub, T. R., \& Lamb, J. (2006). A method for high-throughput gene expression signature analysis. [Research Support, Non-U.S. Gov't]. Genome Biol, 7(7), R61. https://doi.org/10.1186/gb-2006-7-7-r61.

64. Senkus, E., Kyriakides, S., Ohno, S., Penault-Llorca, F., Poortmans, P., Rutgers, E., et al. (2015). Primary breast cancer: ESMO Clinical Practice Guidelines for diagnosis, treatment and follow-up. Annals of Oncology, 26(Suppl 5), v8-30. https://doi. org/10.1093/annonc/mdv298.

65. Sparano, J. A., Gray, R. J., Makower, D. F., Pritchard, K. I., Albain, K. S., Hayes, D. F., et al. (2015). Prospective validation of a 21-gene expression assay in breast cancer. [Randomized Controlled Trial Research Support, N.I.H., Extramural Research Support, Non-U.S. Gov't Validation Studies]. The New England Journal of Medicine, 373(21), 2005-2014. https://doi.org/10. 1056/NEJMoa1510764.

66. Salazar, R., Roepman, P., Capella, G., Moreno, V., Simon, I., Dreezen, C., et al. (2011). Gene expression signature to improve prognosis prediction of stage II and III colorectal cancer. Journal 
of Clinical Oncology, 29(1), 17-24. https://doi.org/10.1200/JCO. 2010.30.1077.

67. Gamazon, E. R., \& Stranger, B. E. (2014). Genomics of alternative splicing: evolution, development and pathophysiology. [Review]. Human Genetics, 133(6), 679-687. https://doi.org/10.1007/ s00439-013-1411-3.

68. Pajares, M. J., Ezponda, T., Catena, R., Calvo, A., Pio, R., \& Montuenga, L. M. (2007). Alternative splicing: an emerging topic in molecular and clinical oncology. [Research Support, Non-U.S. Gov't Review]. The Lancet Oncology, 8(4), 349-357. https://doi. org/10.1016/S1470-2045(07)70104-3.

69. Qu, Y., Dai, B., Ye, D., Kong, Y., Chang, K., Jia, Z., et al. (2015). Constitutively active AR-V7 plays an essential role in the development and progression of castration-resistant prostate cancer. [Research Support, Non-U.S. Gov't]. Scientific Reports, 5, 7654. https://doi.org/10.1038/srep07654.

70. Gan, H. K., Cvrljevic, A. N., \& Johns, T. G. (2013). The epidermal growth factor receptor variant III (EGFRvIII): where wild things are altered. [Research Support, Non-U.S. Gov't Review]. The FEBS Journal, 280(21), 5350-5370. https://doi.org/10.1111/ febs.12393.

71. Zhou, M., Zhong, L., Xu, W., Sun, Y., Zhang, Z., Zhao, H., et al. (2016). Discovery of potential prognostic long non-coding RNA biomarkers for predicting the risk of tumor recurrence of breast cancer patients. Scientific Reports, 6, 31038. https://doi.org/10. 1038/srep31038.

72. Prensner, J. R., Zhao, S., Erho, N., Schipper, M., Iyer, M. K., Dhanasekaran, S. M., et al. (2014). RNA biomarkers associated with metastatic progression in prostate cancer: a multi-institutional high-throughput analysis of SChLAP1. [Comparative Study Multicenter Study Research Support, N.I.H., Extramural Research Support, Non-U.S. Gov't Research Support, U.S. Gov't, Non-P.H.S.] The Lancet Oncology, 15(13), 1469-1480. https://doi.org/10.1016/S1470-2045(14)71113-1.

73. de Kok, J. B., Verhaegh, G. W., Roelofs, R. W., Hessels, D., Kiemeney, L. A., Aalders, T. W., et al. (2002). DD3(PCA3), a very sensitive and specific marker to detect prostate tumors. Cancer Research, 62(9), 2695-2698.

74. Bussemakers, M. J., van Bokhoven, A., Verhaegh, G. W., Smit, F. P., Karthaus, H. F., Schalken, J. A., et al. (1999). DD3: a new prostate-specific gene, highly overexpressed in prostate cancer. [Research Support, Non-U.S. Gov't]. Cancer Research, 59(23), 5975-5979.

75. Luo, X., Burwinkel, B., Tao, S., \& Brenner, H. (2011). MicroRNA signatures: novel biomarker for colorectal cancer? [Review]. Cancer Epidemiology, Biomarkers \& Prevention, 20(7), 12721286. https://doi.org/10.1158/1055-9965.EPI-11-0035.

76. Kelly, B. D., Miller, N., Sweeney, K. J., Durkan, G. C., Rogers, E., Walsh, K., et al. (2015). A circulating microRNA signature as a biomarker for prostate cancer in a high risk group. Journal of Clinical Medicine, 4(7), 1369-1379. https://doi.org/10.3390/ jcm4071369.

77. Li, X., Shi, Y., Yin, Z., Xue, X., \& Zhou, B. (2014). An eightmiRNA signature as a potential biomarker for predicting survival in lung adenocarcinoma. [Research Support, Non-U.S. Gov't]. Journal of Translational Medicine, 12, 159. https://doi.org/10. 1186/1479-5876-12-159.

78. Ouyang, L., Liu, P., Yang, S., Ye, S., Xu, W., \& Liu, X. (2013). A three-plasma miRNA signature serves as novel biomarkers for osteosarcoma. Medical Oncology, 30(1), 340. https://doi.org/10. 1007/s12032-012-0340-7.

79. Macha, M. A., Seshacharyulu, P., Krishn, S. R., Pai, P., Rachagani, S., Jain, M., et al. (2014). MicroRNAs (miRNAs) as biomarker(s) for prognosis and diagnosis of gastrointestinal (GI) cancers. [Research Support, N.I.H., Extramural Review]. Current Pharmaceutical Design, 20(33), 5287-5297.
80. Mitchell, P. S., Parkin, R. K., Kroh, E. M., Fritz, B. R., Wyman, S. K., Pogosova-Agadjanyan, E. L., et al. (2008). Circulating microRNAs as stable blood-based markers for cancer detection. [Research Support, N.I.H., Extramural Research Support, NonU.S. Gov't]. Proceedings of the National Academy of Sciences of the United States of America, 105(30), 10513-10518. https:// doi.org/10.1073/pnas.0804549105.

81. Brase, J. C., Johannes, M., Schlomm, T., Falth, M., Haese, A., Steuber, T., et al. (2011). Circulating miRNAs are correlated with tumor progression in prostate cancer. [Research Support, NonU.S. Gov't]. International Journal of Cancer, 128(3), 608-616. https://doi.org/10.1002/ijc.25376.

82. Cummins, J. M., He, Y., Leary, R. J., Pagliarini, R., Diaz Jr., L. A., Sjoblom, T., et al. (2006). The colorectal microRNAome. Proceedings of the National Academy of Sciences of the United States of America, 103(10), 3687-3692. https://doi.org/10.1073/ pnas. 0511155103 .

83. Liu, G. H., Zhou, Z. G., Chen, R., Wang, M. J., Zhou, B., Li, Y., et al. (2013). Serum miR-21 and miR-92a as biomarkers in the diagnosis and prognosis of colorectal cancer. Tumour Biology, 34(4), 2175-2181. https://doi.org/10.1007/s13277-013-0753-8.

84. Giraldez, M. D., Lozano, J. J., Ramirez, G., Hijona, E., Bujanda, L., Castells, A., et al. (2013). Circulating microRNAs as biomarkers of colorectal cancer: results from a genome-wide profiling and validation study. Clinical Gastroenterology and Hepatology, 11(6), 681-688 e683. https://doi.org/10.1016/j.cgh.2012.12.009.

85. Chen, Q., Xia, H. W., Ge, X. J., Zhang, Y. C., Tang, Q. L., \& Bi, F. (2013). Serum miR-19a predicts resistance to FOLFOX chemotherapy in advanced colorectal cancer cases. Asian Pacific Journal of Cancer Prevention, 14(12), 7421-7426.

86. Bradley, B. P., Shrader, E. A., Kimmel, D. G., \& Meiller, J. C. (2002). Protein expression signatures: an application of proteomics. Marine Environmental Research, 54(3-5), 373-377.

87. Guimaraes, J. C., \& Zavolan, M. (2016). Patterns of ribosomal protein expression specify normal and malignant human cells. Genome Biology, 17(1), 236. https://doi.org/10.1186/s13059016-1104-z.

88. Myers, M. V., Manning, H. C., Coffey, R. J., \& Liebler, D. C. (2012). Protein expression signatures for inhibition of epidermal growth factor receptor-mediated signaling. [Research Support, N.I.H., Extramural]. Molecular and Cellular Probes, 11(2), M111 015222. https://doi.org/10.1074/mcp.M111.015222.

89. Weigel, M. T., \& Dowsett, M. (2010). Current and emerging biomarkers in breast cancer: prognosis and prediction. [Research Support, Non-U.S. Gov't Review]. Endocrine-Related Cancer, 17(4), R245-R262. https://doi.org/10.1677/ERC-10-0136.

90. Dai, X., Xiang, L., Li, T., \& Bai, Z. (2016). Cancer hallmarks, biomarkers and breast cancer molecular subtypes. [Review]. Journal of Cancer, 7(10), 1281-1294. https://doi.org/10.7150/ jca.13141.

91. Chin, K., DeVries, S., Fridlyand, J., Spellman, P. T., Roydasgupta, R., Kuo, W. L., et al. (2006). Genomic and transcriptional aberrations linked to breast cancer pathophysiologies. [Research Support, N.I.H., Extramural Research Support, Non-U.S. Gov't Research Support, U.S. Gov't, Non-P.H.S.] Cancer Cell, 10(6), 529-541. https://doi.org/10.1016/j.ccr.2006.10.009.

92. Farmer, P., Bonnefoi, H., Becette, V., Tubiana-Hulin, M., Fumoleau, P., Larsimont, D., et al. (2005). Identification of molecular apocrine breast tumours by microarray analysis. [Research Support, Non-U.S. Gov't]. Oncogene, 24(29), 4660-4671. https:// doi.org/10.1038/sj.onc.1208561.

93. Rakha, E. A., Reis-Filho, J. S., \& Ellis, I. O. (2010). Combinatorial biomarker expression in breast cancer. [Research Support, Non-U.S. Gov't Review]. Breast Cancer Research and Treatment, 120(2), 293-308. https://doi.org/10.1007/s10549010-0746-x. 
94. Ogawa, Y., Hai, E., Matsumoto, K., Ikeda, K., Tokunaga, S., Nagahara, H., et al. (2008). Androgen receptor expression in breast cancer: relationship with clinicopathological factors and biomarkers. [Research Support, Non-U.S. Gov't]. International Journal of Clinical Oncology, 13(5), 431-435. https://doi.org/10. 1007/s10147-008-0770-6.

95. Viale, G., Giobbie-Hurder, A., Regan, M. M., Coates, A. S., Mastropasqua, M. G., Dell'Orto, P., et al. (2008). Prognostic and predictive value of centrally reviewed Ki-67 labeling index in postmenopausal women with endocrine-responsive breast cancer: results from Breast International Group Trial 1-98 comparing adjuvant tamoxifen with letrozole. [Clinical Trial Clinical Trial, Phase III Randomized Controlled Trial Research Support, N.I.H., Extramural Research Support, Non-U.S. Gov’t]. Journal of Clinical Medicine, 26(34), 5569-5575. https://doi.org/10.1200/ JCO.2008.17.0829.

96. Press, M. F., Sauter, G., Buyse, M., Bernstein, L., Guzman, R., Santiago, A., et al. (2011). Alteration of topoisomerase II-alpha gene in human breast cancer: association with responsiveness to anthracycline-based chemotherapy. [Clinical Trial, Phase III Comparative Study Randomized Controlled Trial Research Support, N.I.H., Extramural Research Support, Non-U.S. Gov't Research Support, U.S. Gov't, Non-P.H.S.] Journal of Clinical Oncology, 29(7), 859-867. https://doi.org/10.1200/JCO.2009.27. 5644.

97. Maris, P., Blomme, A., Palacios, A. P., Costanza, B., Bellahcene, A., Bianchi, E., et al. (2015). Asporin is a fibroblast-derived TGFbeta1 inhibitor and a tumor suppressor associated with good prognosis in breast cancer. [Research Support, Non-U.S. Gov't]. PLoS Medicine, 12(9), e1001871. https://doi.org/10.1371/journal.pmed. 1001871.

98. Prensner, J. R., Rubin, M. A., Wei, J. T., \& Chinnaiyan, A. M. (2012). Beyond PSA: the next generation of prostate cancer biomarkers. [Research Support, N.I.H., Extramural Research Support, Non-U.S. Gov’t Research Support, U.S. Gov’t, NonP.H.S. Review]. Science Translational Medicine, 4(127), 127rv123. https://doi.org/10.1126/scitranslmed.3003180.

99. Lilja, H., Ulmert, D., \& Vickers, A. J. (2008). Prostate-specific antigen and prostate cancer: prediction, detection and monitoring. [Review]. Nature Reviews. Cancer, 8(4), 268-278. https://doi.org/ 10.1038/nrc2351.

100. Balk, S. P., Ko, Y. J., \& Bubley, G. J. (2003). Biology of prostatespecific antigen. [Research Support, Non-U.S. Gov't Research Support, U.S. Gov't, P.H.S. Review]. Journal of Clinical Oncology, 21(2), 383-391. https://doi.org/10.1200/JCO.2003.02. 083.

101. Corrado, M., Scorrano, L., \& Campello, S. (2016). Changing perspective on oncometabolites: from metabolic signature of cancer to tumorigenic and immunosuppressive agents. [Review]. Oncotarget, 7(29), 46692-46706. https://doi.org/10.18632/ oncotarget.8727.

102. Mishra, P., \& Ambs, S. (2015). Metabolic signatures of human breast cancer. Molecular \& Cellular Oncology, 2(3). https://doi. org/10.4161/23723556.2014.992217.

103. von Rundstedt, F. C., Rajapakshe, K., Ma, J., Arnold, J. M., Gohlke, J., Putluri, V., et al. (2016). Integrative pathway analysis of metabolic signature in bladder cancer: a linkage to the cancer genome atlas project and prediction of survival. The Journal of Urology, 195(6), 1911-1919. https://doi.org/10.1016/j.juro.2016. 01.039 .

104. Reitman, Z. J., Jin, G., Karoly, E. D., Spasojevic, I., Yang, J., Kinzler, K. W., et al. (2011). Profiling the effects of isocitrate dehydrogenase 1 and 2 mutations on the cellular metabolome. [Research Support, N.I.H., Extramural Research Support, NonU.S. Gov't]. Proceedings of the National Academy of Sciences of the United States of America, 108(8), 3270-3275. https://doi. org/10.1073/pnas.1019393108.

105. Dang, L., White, D. W., Gross, S., Bennett, B. D., Bittinger, M. A., Driggers, E. M., et al. (2010). Cancer-associated IDH1 mutations produce 2-hydroxyglutarate. Nature, 465(7300), 966. https://doi. org/10.1038/nature09132.

106. Ward, P. S., Patel, J., Wise, D. R., Abdel-Wahab, O., Bennett, B. D., Coller, H. A., et al. (2010). The common feature of leukemiaassociated IDH1 and IDH2 mutations is a neomorphic enzyme activity converting alpha-ketoglutarate to 2-hydroxyglutarate. [Research Support, N.I.H., Extramural]. Cancer Cell, 17(3), 225-234. https://doi.org/10.1016/j.ccr.2010.01.020.

107. Logozzi, M., De Milito, A., Lugini, L., Borghi, M., Calabro, L., Spada, M., et al. (2009). High levels of exosomes expressing CD63 and caveolin-1 in plasma of melanoma patients. PLoS One, 4(4), e5219. https://doi.org/10.1371/journal.pone.0005219.

108. Sandfeld-Paulsen, B., Aggerholm-Pedersen, N., Baek, R., Jakobsen, K. R., Meldgaard, P., Folkersen, B. H., et al. (2016). Exosomal proteins as prognostic biomarkers in non-small cell lung cancer. Molecular Oncology, 10(10), 1595-1602. https:// doi.org/10.1016/j.molonc.2016.10.003.

109. Sandfeld-Paulsen, B., Jakobsen, K. R., Baek, R., Folkersen, B. H., Rasmussen, T. R., Meldgaard, P., et al. (2016). Exosomal proteins as diagnostic biomarkers in lung cancer. Journal of Thoracic Oncology, 11(10), 1701-1710. https://doi.org/10.1016/j.jtho. 2016.05.034.

110. Yoshioka, Y., Konishi, Y., Kosaka, N., Katsuda, T., Kato, T., \& Ochiya, T. (2013). Comparative marker analysis of extracellular vesicles in different human cancer types. Journal of Extracellular Vesicles, 2. https://doi.org/10.3402/jev.v2i0.20424.

111. Blomme, A., Fahmy, K., Peulen, O., Costanza, B., Fontaine, M., Struman, I., et al. (2016). Myoferlin is a novel exosomal protein and functional regulator of cancer-derived exosomes. Oncotarget, 7(50), 83669-83683. https://doi.org/10.18632/oncotarget.13276.

112. Blomme, A., Costanza, B., de Tullio, P., Thiry, M., Van Simaeys, G., Boutry, S., et al. (2016). Myoferlin regulates cellular lipid metabolism and promotes metastases in triple-negative breast cancer. Oncogene. https://doi.org/10.1038/onc.2016.369.

113. Turtoi, A., Blomme, A., Bellahcene, A., Gilles, C., Hennequiere, V., Peixoto, P., et al. (2013). Myoferlin is a key regulator of EGFR activity in breast cancer. [Research Support, Non-U.S. Gov't]. Cancer Research, 73(17), 5438-5448. https://doi.org/10.1158/ 0008-5472.CAN-13-1142.

114. Fahmy, K., Gonzalez, A., Arafa, M., Peixoto, P., Bellahcene, A., Turtoi, A., et al. (2016). Myoferlin plays a key role in VEGFA secretion and impacts tumor-associated angiogenesis in human pancreas cancer. [Research Support, Non-U.S. Gov't]. International Journal of Cancer, 138(3), 652-663. https://doi. org/10.1002/ijc.29820.

115. Valadi, H., Ekstrom, K., Bossios, A., Sjostrand, M., Lee, J. J., \& Lotvall, J. O. (2007). Exosome-mediated transfer of mRNAs and microRNAs is a novel mechanism of genetic exchange between cells. [Research Support, Non-U.S. Gov't]. Nature Cell Biology, 9(6), 654-659. https://doi.org/10.1038/ncb1596.

116. Nilsson, J., Skog, J., Nordstrand, A., Baranov, V., MinchevaNilsson, L., Breakefield, X. O., et al. (2009). Prostate cancerderived urine exosomes: a novel approach to biomarkers for prostate cancer. [Research Support, N.I.H., Extramural Research Support, Non-U.S. Gov’t Validation Studies]. British Journal of Cancer, 100(10), 1603-1607. https://doi.org/10.1038/sj.bjc. 6605058.

117. Nilsson, R. J., Balaj, L., Hulleman, E., van Rijn, S., Pegtel, D. M., Walraven, M., et al. (2011). Blood platelets contain tumor-derived RNA biomarkers. [Research Support, Non-U.S. Gov't]. Blood, 118(13), 3680-3683. https://doi.org/10.1182/blood-2011-03344408 . 
118. Taylor, D. D., \& Gercel-Taylor, C. (2008). MicroRNA signatures of tumor-derived exosomes as diagnostic biomarkers of ovarian cancer. [Research Support, N.I.H., Extramural Research Support, Non-U.S. Gov't]. Gynecologic Oncology, 110(1), 13-21. https:// doi.org/10.1016/j.ygyno.2008.04.033.

119. Rabinowits, G., Gercel-Taylor, C., Day, J. M., Taylor, D. D., \& Kloecker, G. H. (2009). Exosomal microRNA: a diagnostic marker for lung cancer. Clinical Lung Cancer, 10(1), 42-46. https://doi. org/10.3816/CLC.2009.n.006.

120. Haick, H., Broza, Y. Y., Mochalski, P., Ruzsanyi, V., \& Amann, A. (2014). Assessment, origin, and implementation of breath volatile cancer markers. Chemical Society Reviews, 43(5), 1423-1449. https://doi.org/10.1039/c3cs60329f.

121. Cornu, J. N., Cancel-Tassin, G., Ondet, V., Girardet, C., \& Cussenot, O. (2011). Olfactory detection of prostate cancer by dogs sniffing urine: a step forward in early diagnosis. European Urology, 59(2), 197-201. https://doi.org/10.1016/j.eururo.2010. 10.006

122. Willis, C. M., Church, S. M., Guest, C. M., Cook, W. A., McCarthy, N., Bransbury, A. J., et al. (2004). Olfactory detection of human bladder cancer by dogs: proof of principle study. BMJ, 329(7468), 712. https://doi.org/10.1136/bmj.329.7468.712.

123. Fuchs, P., Loeseken, C., Schubert, J. K., \& Miekisch, W. (2010). Breath gas aldehydes as biomarkers of lung cancer. International Journal of Cancer, 126(11), 2663-2670. https://doi.org/10.1002/ ijc. 24970 .

124. Song, G., Qin, T., Liu, H., Xu, G. B., Pan, Y. Y., Xiong, F. X., et al. (2010). Quantitative breath analysis of volatile organic compounds of lung cancer patients. Lung Cancer, 67(2), 227-231. https://doi.org/10.1016/j.lungcan.2009.03.029.

125. Wang, Y., Hu, Y., Wang, D., Yu, K., Wang, L., Zou, Y., et al. (2012). The analysis of volatile organic compounds biomarkers for lung cancer in exhaled breath, tissues and cell lines. Cancer Biomarkers, 11(4), 129-137. https://doi.org/10.3233/CBM-201200270.

126. Handa, H., Usuba, A., Maddula, S., Baumbach, J. I., Mineshita, M., \& Miyazawa, T. (2014). Exhaled breath analysis for lung cancer detection using ion mobility spectrometry. PLoS One, 9(12), e114555. https://doi.org/10.1371/journal.pone.0114555.

127. Zou, Y., Zhang, X., Chen, X., Hu, Y., Ying, K., \& Wang, P. (2014). Optimization of volatile markers of lung cancer to exclude interferences of non-malignant disease. Cancer Biomarkers, 14(5), 371-379. https://doi.org/10.3233/CBM-140418.

128. Mangler, M., Freitag, C., Lanowska, M., Staeck, O., Schneider, A., \& Speiser, D. (2012). Volatile organic compounds (VOCs) in exhaled breath of patients with breast cancer in a clinical setting. Ginekologia Polska, 83(10), 730-736.

129. Qin, T., Liu, H., Song, Q., Song, G., Wang, H. Z., Pan, Y. Y., et al. (2010). The screening of volatile markers for hepatocellular carcinoma. Cancer Epidemiology, Biomarkers \& Prevention, 19(9), 2247-2253. https://doi.org/10.1158/1055-9965.EPI-10-0302.

130. Turtoi, A., De Pauw, E., \& Castronovo, V. (2011). Innovative proteomics for the discovery of systemically accessible cancer biomarkers suitable for imaging and targeted therapies. [Research Support, Non-U.S. Gov't Review]. The American Journal of Pathology, 178(1), 12-18. https://doi.org/10.1016/j. ajpath.2010.08.004

131. Dijkers, E. C., Kosterink, J. G., Rademaker, A. P., Perk, L. R., van Dongen, G. A., Bart, J., et al. (2009). Development and characterization of clinical-grade $89 \mathrm{Zr}$-trastuzumab for HER2/neu immunoPET imaging. [Research Support, Non-U.S. Gov't]. Journal of Nuclear Medicine, 50(6), 974-981. https://doi.org/10. 2967/jnumed.108.060392.

132. Dijkers, E. C., Oude Munnink, T. H., Kosterink, J. G., Brouwers, A. H., Jager, P. L., de Jong, J. R., et al. (2010). Biodistribution of 89Zr-trastuzumab and PET imaging of HER2-positive lesions in patients with metastatic breast cancer. [Comparative Study Research Support, Non-U.S. Gov't]. Clinical Pharmacology and Therapeutics, 87(5), 586-592. https://doi.org/10.1038/clpt.2010. 12.

133. Orlova, A., Wallberg, H., Stone-Elander, S., \& Tolmachev, V. (2009). On the selection of a tracer for PET imaging of HER2expressing tumors: direct comparison of a 124I-labeled affibody molecule and trastuzumab in a murine xenograft model. [Comparative Study Research Support, Non-U.S. Gov't]. Journal of Nuclear Medicine, 50(3), 417-425. https://doi.org/10. 2967/jnumed.108.057919.

134. Tolmachev, V., Velikyan, I., Sandstrom, M., \& Orlova, A. (2010). A HER2-binding affibody molecule labelled with $68 \mathrm{Ga}$ for PET imaging: direct in vivo comparison with the 111In-labelled analogue. [Comparative Study Research Support, Non-U.S. Gov't]. European Journal of Nuclear Medicine and Molecular Imaging, 37(7), 1356-1367. https://doi.org/10.1007/s00259-009-1367-7.

135. Sorensen, J., Sandberg, D., Sandstrom, M., Wennborg, A., Feldwisch, J., Tolmachev, V., et al. (2014). First-in-human molecular imaging of HER2 expression in breast cancer metastases using the $111 \mathrm{In}-\mathrm{ABY}-025$ affibody molecule. [Clinical Trial, Phase I Clinical Trial, Phase II Research Support, Non-U.S. Gov't]. Journal of Nuclear Medicine, 55(5), 730-735. https:// doi.org/10.2967/jnumed.113.131243.

136. Wu, X., Liu, H., Liu, J., Haley, K. N., Treadway, J. A., Larson, J. P., et al. (2003). Immunofluorescent labeling of cancer marker Her2 and other cellular targets with semiconductor quantum dots. [Evaluation Studies Research Support, U.S. Gov't, P.H.S. Validation Studies]. Nature Biotechnology, 21(1), 41-46. https:// doi.org/10.1038/nbt764.

137. Kaspar, M., Zardi, L., \& Neri, D. (2006). Fibronectin as target for tumor therapy. [Review]. International Journal of Cancer, 118(6), 1331-1339. https://doi.org/10.1002/ijc.21677.

138. Neri, D., \& Bicknell, R. (2005). Tumour vascular targeting. [Research Support, Non-U.S. Gov't Review]. Nature Reviews. Cancer, 5(6), 436-446. https://doi.org/10.1038/nrc1627.

139. Silacci, M., Brack, S. S., Spath, N., Buck, A., Hillinger, S., Arni, S., et al. (2006). Human monoclonal antibodies to domain $\mathrm{C}$ of tenascin-C selectively target solid tumors in vivo. [Research Support, Non-U.S. Gov't]. Protein Engineering, Design \& Selection, 19(10), 471-478. https://doi.org/10.1093/protein/ gzl033.

140. Schena, M., Shalon, D., Davis, R. W., \& Brown, P. O. (1995). Quantitative monitoring of gene expression patterns with a complementary DNA microarray. [Research Support, Non-U.S. Gov't Research Support, U.S. Gov’t, Non-P.H.S. Research Support, U.S. Gov't, P.H.S.] Science, 270(5235), 467-470.

141. Liu, Y., \& Guo, M. (2014). Chemical proteomic strategies for the discovery and development of anticancer drugs. [Research Support, Non-U.S. Gov't Review]. Proteomics, 14(4-5), 399411. https://doi.org/10.1002/pmic.201300261.

142. Rix, U., \& Superti-Furga, G. (2009). Target profiling of small molecules by chemical proteomics. [Research Support, NonU.S. Gov’t Review]. Nature Chemical Biology, 5(9), 616-624. https://doi.org/10.1038/nchembio.216.

143. Huang, F., Zhang, B., Zhou, S., Zhao, X., Bian, C., \& Wei, Y. (2012). Chemical proteomics: terra incognita for novel drug target profiling. [Research Support, Non-U.S. Gov't Review]. Chinese Journal of Cancer, 31(11), 507-518. https://doi.org/10.5732/cjc. 011.10377.

144. Wang, K., Yang, T., Wu, Q., Zhao, X., Nice, E. C., \& Huang, C. (2012). Chemistry-based functional proteomics for drug target deconvolution. [Research Support, Non-U.S. Gov't Review]. Expert Review of Proteomics, 9(3), 293-310. https://doi.org/10. 1586/epr.12.19. 
145. Kischel, P., Waltregny, D., \& Castronovo, V. (2007). Identification of accessible human cancer biomarkers using ex vivo chemical proteomic strategies. [Research Support, Non-U.S. Gov't Review]. Expert Review of Proteomics, 4(6), 727-739. https:// doi.org/10.1586/14789450.4.6.727.

146. Rybak, J. N., Ettorre, A., Kaissling, B., Giavazzi, R., Neri, D., \& Elia, G. (2005). In vivo protein biotinylation for identification of organ-specific antigens accessible from the vasculature. [Evaluation Studies Research Support, Non-U.S. Gov't]. Nature Methods, 2(4), 291-298. https://doi.org/10.1038/nmeth745.

147. Roesli, C., Neri, D., \& Rybak, J. N. (2006). In vivo protein biotinylation and sample preparation for the proteomic identification of organ- and disease-specific antigens accessible from the vasculature. [Research Support, Non-U.S. Gov't]. Nature Protocols, 1(1), 192-199. https://doi.org/10.1038/nprot.2006.29.

148. Castronovo, V., Kischel, P., Guillonneau, F., de Leval, L., Defechereux, T., De Pauw, E., et al. (2007). Identification of specific reachable molecular targets in human breast cancer using a versatile ex vivo proteomic method. [Evaluation Studies Research Support, Non-U.S. Gov't]. Proteomics, 7(8), 1188-1196. https:// doi.org/10.1002/pmic.200600888.

149. Castronovo, V., Waltregny, D., Kischel, P., Roesli, C., Elia, G., Rybak, J. N., et al. (2006). A chemical proteomics approach for the identification of accessible antigens expressed in human kidney cancer. [Research Support, Non-U.S. Gov't]. Molecular \& Cellular Proteomics, 5(11), 2083-2091. https://doi.org/10.1074/ mcp.M600164-MCP200.

150. Turtoi, A., Dumont, B., Greffe, Y., Blomme, A., Mazzucchelli, G., Delvenne, P., et al. (2011). Novel comprehensive approach for accessible biomarker identification and absolute quantification from precious human tissues. [Research Support, Non-U.S. Gov't]. Journal of Proteome Research, 10(7), 3160-3182. https://doi.org/10.1021/pr200212r.

151. Turtoi, A., Musmeci, D., Wang, Y., Dumont, B., Somja, J., Bevilacqua, G., et al. (2011). Identification of novel accessible proteins bearing diagnostic and therapeutic potential in human pancreatic ductal adenocarcinoma. [Research Support, Non-U.S. Gov’t]. Journal of Proteome Research, 10(9), 4302-4313. https:// doi.org/10.1021/pr200527z.

152. Conrotto, P., Roesli, C., Rybak, J., Kischel, P., Waltregny, D., Neri, D., et al. (2008). Identification of new accessible tumor antigens in human colon cancer by ex vivo protein biotinylation and comparative mass spectrometry analysis. [Comparative Study Research Support, Non-U.S. Gov't]. International Journal of Cancer, 123(12), 2856-2864. https://doi.org/10.1002/ijc.23861.

153. Borgia, B., Roesli, C., Fugmann, T., Schliemann, C., Cesca, M., Neri, D., et al. (2010). A proteomic approach for the identification of vascular markers of liver metastasis. [Research Support, NonU.S. Gov't]. Cancer Research, 70(1), 309-318. https://doi.org/10. 1158/0008-5472.CAN-09-2939.

154. Schliemann, C., Roesli, C., Kamada, H., Borgia, B., Fugmann, T., Klapper, W., et al. (2010). In vivo biotinylation of the vasculature in B-cell lymphoma identifies BST-2 as a target for antibodybased therapy. [Evaluation Studies Research Support, Non-U.S. Gov't]. Blood, 115(3), 736-744. https://doi.org/10.1182/blood2009-08-239004.

155. Wollscheid, B., Bausch-Fluck, D., Henderson, C., O'Brien, R., Bibel, M., Schiess, R., et al. (2009). Mass-spectrometric identification and relative quantification of N-linked cell surface glycoproteins. [Research Support, N.I.H., Extramural Research Support, Non-U.S. Gov't]. Nature Biotechnology, 27(4), 378386. https://doi.org/10.1038/nbt.1532.

156. Zhang, H., Li, X. J., Martin, D. B., \& Aebersold, R. (2003). Identification and quantification of N-linked glycoproteins using hydrazide chemistry, stable isotope labeling and mass spectrometry. [Evaluation Studies Research Support, Non-U.S. Gov’t
Research Support, U.S. Gov't, P.H.S. Validation Studies]. Nature Biotechnology, 21(6), 660-666. https://doi.org/10.1038/ nbt827.

157. Tian, Y., Zhou, Y., Elliott, S., Aebersold, R., \& Zhang, H. (2007). Solid-phase extraction of N-linked glycopeptides. [Research Support, N.I.H., Extramural]. Nature Protocols, 2(2), 334-339. https://doi.org/10.1038/nprot.2007.42.

158. Celis, J. E., Gromov, P., Cabezon, T., Moreira, J. M., Ambartsumian, N., Sandelin, K., et al. (2004). Proteomic characterization of the interstitial fluid perfusing the breast tumor microenvironment: a novel resource for biomarker and therapeutic target discovery. Molecular \& Cellular Proteomics, 3(4), 327-344. https://doi.org/10.1074/mcp.M400009-MCP200.

159. Fijneman, R. J., de Wit, M., Pourghiasian, M., Piersma, S. R., Pham, T. V., Warmoes, M. O., et al. (2012). Proximal fluid proteome profiling of mouse colon tumors reveals biomarkers for early diagnosis of human colorectal cancer. Clinical Cancer Research, 18(9), 2613-2624. https://doi.org/10.1158/1078-0432.CCR-111937.

160. de Wit, M., Fijneman, R. J., Verheul, H. M., Meijer, G. A., \& Jimenez, C. R. (2013). Proteomics in colorectal cancer translational research: biomarker discovery for clinical applications. Clinical Biochemistry, 46(6), 466-479. https://doi.org/10.1016/j. clinbiochem.2012.10.039.

161. de Wit, M., Kant, H., Piersma, S. R., Pham, T. V., Mongera, S., van Berkel, M. P., et al. (2014). Colorectal cancer candidate biomarkers identified by tissue secretome proteome profiling. [Clinical Trial Research Support, Non-U.S. Gov't]. Journal of Proteomics, 99, 26-39. https://doi.org/10.1016/j.jprot.2014.01. 001.

162. Raso, C., Cosentino, C., Gaspari, M., Malara, N., Han, X., McClatchy, D., et al. (2012). Characterization of breast cancer interstitial fluids by TmT labeling, LTQ-Orbitrap Velos mass spectrometry, and pathway analysis. Journal of Proteome Research, 11(6), 3199-3210. https://doi.org/10.1021/pr2012347.

163. Teng, P. N., Hood, B. L., Sun, M., Dhir, R., \& Conrads, T. P. (2011). Differential proteomic analysis of renal cell carcinoma tissue interstitial fluid. [Evaluation Studies Research Support, Non-U.S. Gov't]. Journal of Proteome Research, 10(3), 13331342. https://doi.org/10.1021/pr101074p.

164. Dabrosin, C. (2005). Microdialysis - an in vivo technique for studies of growth factors in breast cancer. Frontiers in Bioscience, 10, 1329-1335.

165. Huang, C. M., Nakatsuji, T., Liu, Y. T., \& Shi, Y. (2008). In vivo tumor secretion probing via ultrafiltration and tissue chamber: implication for anti-cancer drugs targeting secretome. Recent Patents on Anti-Cancer Drug Discovery, 3(1), 48-54.

166. Huang, C. M., Ananthaswamy, H. N., Barnes, S., Ma, Y., Kawai, M., \& Elmets, C. A. (2006). Mass spectrometric proteomics profiles of in vivo tumor secretomes: capillary ultrafiltration sampling of regressive tumor masses. Proteomics, 6(22), 6107-6116. https://doi.org/10.1002/pmic.200600287.

167. Wiig, H., Aukland, K., \& Tenstad, O. (2003). Isolation of interstitial fluid from rat mammary tumors by a centrifugation method. American Journal of Physiology. Heart and Circulatory Physiology, 284(1), H416-H424. https://doi.org/10.1152/ ajpheart.00327.2002.

168. Haslene-Hox, H., Tenstad, O., \& Wiig, H. (2013). Interstitial fluida reflection of the tumor cell microenvironment and secretome. Biochimica et Biophysica Acta, 1834(11), 2336-2346. https:// doi.org/10.1016/j.bbapap.2013.01.028.

169. Hoskins, E. R., Hood, B. L., Sun, M., Krivak, T. C., Edwards, R. P., \& Conrads, T. P. (2011). Proteomic analysis of ovarian cancer proximal fluids: validation of elevated peroxiredoxin 1 in patient peripheral circulation. [Research Support, Non-U.S. Gov't]. PLoS One, 6(9), e25056. https://doi.org/10.1371/journal.pone.0025056. 
170. Sun, W., Ma, J., Wu, S., Yang, D., Yan, Y., Liu, K., et al. (2010). Characterization of the liver tissue interstitial fluid (TIF) proteome indicates potential for application in liver disease biomarker discovery. Journal of Proteome Research, 9(2), 1020-1031. https:// doi.org/10.1021/pr9009172.

171. Gromov, P., Gromova, I., Bunkenborg, J., Cabezon, T., Moreira, J. M., Timmermans-Wielenga, V., et al. (2010). Up-regulated proteins in the fluid bathing the tumour cell microenvironment as potential serological markers for early detection of cancer of the breast. Molecular Oncology, 4(1), 65-89. https://doi.org/10.1016/ j.molonc.2009.11.003.

172. Wang, Y., Shan, Q., Hou, G., Zhang, J., Bai, J., Lv, X., et al. (2016). Discovery of potential colorectal cancer serum biomarkers through quantitative proteomics on the colonic tissue interstitial fluids from the AOM-DSS mouse model. Journal of Proteomics, 132, 31-40. https://doi.org/10.1016/j.jprot.2015.11.013.

173. Huminiecki, L., \& Bicknell, R. (2000). In silico cloning of novel endothelial-specific genes. [Comparative Study]. Genome Research, 10(11), 1796-1806.

174. Jensen, L. J., Kuhn, M., Stark, M., Chaffron, S., Creevey, C., Muller, J., et al. (2009). STRING 8-a global view on proteins and their functional interactions in 630 organisms. [Research Support, Non-U.S. Gov't]. Nucleic Acids Research, 37(Database issue), D412-D416. https://doi.org/10.1093/nar/gkn760.

175. Fugmann, T., Neri, D., \& Roesli, C. (2010). DeepQuanTR: MALDI-MS-based label-free quantification of proteins in complex biological samples. [Research Support, Non-U.S. Gov't]. Proteomics, 10(14), 2631-2643. https://doi.org/10.1002/pmic. 200900634.

176. Hassan, S., Ferrario, C., Mamo, A., \& Basik, M. (2008). Tissue microarrays: emerging standard for biomarker validation. [Review Validation Studies]. Current Opinion in Biotechnology, 19(1), 1925. https://doi.org/10.1016/j.copbio.2007.10.009.

177. Camp, R. L., Neumeister, V., \& Rimm, D. L. (2008). A decade of tissue microarrays: progress in the discovery and validation of cancer biomarkers. [Review]. Journal of Clinical Oncology, 26(34), 5630-5637. https://doi.org/10.1200/JCO.2008.17.3567.

178. Schoenberg Fejzo, M., \& Slamon, D. J. (2001). Frozen tumor tissue microarray technology for analysis of tumor RNA, DNA, and proteins. [Research Support, Non-U.S. Gov't]. The American Journal of Pathology, 159(5), 1645-1650. https://doi.org/10. 1016/S0002-9440(10)63011-8.

179. Datta, M. W., Kahler, A., Macias, V., Brodzeller, T., \& KajdacsyBalla, A. (2005). A simple inexpensive method for the production of tissue microarrays from needle biopsy specimens: examples with prostate cancer. [Research Support, N.I.H., Extramural Research Support, Non-U.S. Gov't Research Support, U.S. Gov't, P.H.S.] Applied Immunohistochemistry \& Molecular Morphology, 13(1), 96-103.

180. Parker, C. E., \& Borchers, C. H. (2014). Mass spectrometry based biomarker discovery, verification, and validation-quality assurance and control of protein biomarker assays. [Research Support, Non-U.S. Gov't Review]. Molecular Oncology, 8(4), 840-858. https://doi.org/10.1016/j.molonc.2014.03.006.

181. Rifai, N., Gillette, M. A., \& Carr, S. A. (2006). Protein biomarker discovery and validation: the long and uncertain path to clinical utility. [Research Support, N.I.H., Extramural Research Support, Non-U.S. Gov’t Review]. Nature Biotechnology, 24(8), 971-983. https://doi.org/10.1038/nbt1235.

182. Anderson, N. L., Anderson, N. G., Haines, L. R., Hardie, D. B., Olafson, R. W., \& Pearson, T. W. (2004). Mass spectrometric quantitation of peptides and proteins using stable isotope standards and capture by anti-peptide antibodies (SISCAPA). [Research Support, Non-U.S. Gov't]. Journal of Proteome Research, 3(2), 235-244.
183. Whiteaker, J. R., Zhao, L., Zhang, H. Y., Feng, L. C., Piening, B. D., Anderson, L., et al. (2007). Antibody-based enrichment of peptides on magnetic beads for mass-spectrometry-based quantification of serum biomarkers. [Research Support, N.I.H., Extramural Research Support, Non-U.S. Gov't]. Analytical Biochemistry, 362(1), 44-54. https://doi.org/10.1016/j.ab.2006. 12.023 .

184. Malou, N., \& Raoult, D. (2011). Immuno-PCR: a promising ultrasensitive diagnostic method to detect antigens and antibodies. [Evaluation Studies Review]. Trends in Microbiology, 19(6), 295-302. https://doi.org/10.1016/j.tim.2011.03.004.

185. Dasilva, N., Diez, P., Matarraz, S., Gonzalez-Gonzalez, M., Paradinas, S., Orfao, A., et al. (2012). Biomarker discovery by novel sensors based on nanoproteomics approaches. [Research Support, Non-U.S. Gov't Review]. Sensors (Basel), 12(2), 2284-2308. https://doi.org/10.3390/s120202284.

186. Gygi, S. P., Rist, B., Gerber, S. A., Turecek, F., Gelb, M. H., \& Aebersold, R. (1999). Quantitative analysis of complex protein mixtures using isotope-coded affinity tags. [Research Support, Non-U.S. Gov't Research Support, U.S. Gov't, Non-P.H.S. Research Support, U.S. Gov't, P.H.S.] Nature Biotechnology, 17(10), 994-999. https://doi.org/10.1038/13690.

187. Oh, P., Li, Y., Yu, J., Durr, E., Krasinska, K. M., Carver, L. A., et al. (2004). Subtractive proteomic mapping of the endothelial surface in lung and solid tumours for tissue-specific therapy. [Research Support, Non-U.S. Gov't Research Support, U.S. Gov't, P.H.S.] Nature, 429(6992), 629-635. https://doi.org/10. 1038/nature02580.

188. Pasqualini, R., \& Ruoslahti, E. (1996). Organ targeting in vivo using phage display peptide libraries. [Research Support, NonU.S. Gov't Research Support, U.S. Gov't, P.H.S.] Nature, 380(6572), 364-366. https://doi.org/10.1038/380364a0.

189. Weigl, B. H., Bardell, R. L., \& Cabrera, C. R. (2003). Lab-on-achip for drug development. [Review]. Advanced Drug Delivery Reviews, 55(3), 349-377.

190. Febbo, P. G., Ladanyi, M., Aldape, K. D., De Marzo, A. M., Hammond, M. E., Hayes, D. F., et al. (2011). NCCN Task Force report: evaluating the clinical utility of tumor markers in oncology. Journal of the National Comprehensive Cancer Network, 9(Suppl 5), S1-32 quiz S33.

191. Jamal-Hanjani, M., Quezada, S. A., Larkin, J., \& Swanton, C. (2015). Translational implications of tumor heterogeneity. [Research Support, Non-U.S. Gov't Review]. Clinical Cancer Research, 21(6), 1258-1266. https://doi.org/10.1158/1078-0432. CCR-14-1429.

192. Espina, V., Wulfkuhle, J. D., Calvert, V. S., VanMeter, A., Zhou, W., Coukos, G., et al. (2006). Laser-capture microdissection. Nature Protocols, 1(2), 586-603. https://doi.org/10.1038/nprot. 2006.85.

193. Baker, H., Patel, V., Molinolo, A. A., Shillitoe, E. J., Ensley, J. F., Yoo, G. H., et al. (2005). Proteome-wide analysis of head and neck squamous cell carcinomas using laser-capture microdissection and tandem mass spectrometry. Oral Oncology, 41(2), 183-199. https://doi.org/10.1016/j.oraloncology.2004.08.009.

194. Li, C., Hong, Y., Tan, Y. X., Zhou, H., Ai, J. H., Li, S. J., et al. (2004). Accurate qualitative and quantitative proteomic analysis of clinical hepatocellular carcinoma using laser capture microdissection coupled with isotope-coded affinity tag and twodimensional liquid chromatography mass spectrometry. [Comparative Study Research Support, Non-U.S. Gov't]. Molecular \& Cellular Proteomics, 3(4), 399-409. https://doi.org/ 10.1074/mcp.M300133-MCP200.

195. Dirks, R. A., Stunnenberg, H. G., \& Marks, H. (2016). Genomewide epigenomic profiling for biomarker discovery. [Review]. Clinical Epigenetics, 8, 122. https://doi.org/10.1186/s13148-0160284-4. 
196. Anderson, N. L., \& Anderson, N. G. (2002). The human plasma proteome: history, character, and diagnostic prospects. Molecular \& Cellular Proteomics, 1(11), 845-867.

197. States, D. J., Omenn, G. S., Blackwell, T. W., Fermin, D., Eng, J., Speicher, D. W., et al. (2006). Challenges in deriving highconfidence protein identifications from data gathered by a HUPO plasma proteome collaborative study. [Comparative Study Research Support, N.I.H., Extramural Research Support, Non-U.S. Gov't]. Nature Biotechnology, 24(3), 333-338. https:// doi.org/10.1038/nbt1183.

198. Jacobs, J. M., Adkins, J. N., Qian, W. J., Liu, T., Shen, Y., Camp 2nd, D. G., et al. (2005). Utilizing human blood plasma for proteomic biomarker discovery. [Research Support, N.I.H., Extramural Research Support, U.S. Gov't, Non-P.H.S. Research Support, U.S. Gov't, P.H.S. Review]. Journal of Proteome Research, 4(4), 1073-1085. https://doi.org/10.1021/pr0500657.

199. Bodzon-Kulakowska, A., Bierczynska-Krzysik, A., Dylag, T., Drabik, A., Suder, P., Noga, M., et al. (2007). Methods for samples preparation in proteomic research. [Research Support, Non-U.S. Gov't Review]. Journal of Chromatography. B, Analytical Technologies in the Biomedical and Life Sciences, 849(1-2), 131. https://doi.org/10.1016/j.jchromb.2006.10.040.

200. Feist, P., \& Hummon, A. B. (2015). Proteomic challenges: sample preparation techniques for microgram-quantity protein analysis from biological samples. [Research Support, N.I.H., Extramural Research Support, Non-U.S. Gov't Research Support, U.S. Gov't, Non-P.H.S. Review]. International Journal of Molecular Sciences, 16(2), 3537-3563. https://doi.org/10.3390/ ijms16023537.

201. Bodovitz, S., \& Joos, T. (2004). The proteomics bottleneck: strategies for preliminary validation of potential biomarkers and drug targets. [Evaluation Studies Validation Studies]. Trends in Biotechnology, 22(1), 4-7. https://doi.org/10.1016/j.tibtech.2003. 10.013 .

202. Anderson, R., O'Hare, M., Balls, M., Brady, M., Brahams, D., Burt, A., et al. (1998). The availability of human tissue for biomedical research: the Report and Recommendations of the ECVAM Workshop 32. [Guideline]. Alternatives to Laboratory Animals, 26(6), 763-777.

203. Riondino, S., Ferroni, P., Spila, A., Alessandroni, J., D'Alessandro, R., Formica, V., et al. (2015). Ensuring sample quality for biomarker discovery studies - use of ICT tools to trace biosample life-cycle. [Research Support, Non-U.S. Gov't Review]. Cancer Genomics Proteomics, 12(6), 291-299.

204. Zehetmayer, S., Bauer, P., \& Posch, M. (2005). Two-stage designs for experiments with a large number of hypotheses. [Evaluation Studies Research Support, Non-U.S. Gov't]. Bioinformatics, 21(19), 3771-3777. https://doi.org/10.1093/bioinformatics/ bti604.

205. Wallstrom, G., Anderson, K. S., \& LaBaer, J. (2013). Biomarker discovery for heterogeneous diseases. Cancer Epidemiology, Biomarkers \& Prevention, 22(5), 747-755. https://doi.org/10. 1158/1055-9965.EPI-12-1236.

206. Hiley, C., de Bruin, E. C., McGranahan, N., \& Swanton, C. (2014). Deciphering intratumor heterogeneity and temporal acquisition of driver events to refine precision medicine. [Research Support, Non-U.S. Gov’t Review]. Genome Biology, 15(8), 453. https://doi.org/10.1186/s13059-014-0453-8.

207. Jamal-Hanjani, M., Hackshaw, A., Ngai, Y., Shaw, J., Dive, C., Quezada, S., et al. (2014). Tracking genomic cancer evolution for precision medicine: the lung TRACERx study. [Research Support, Non-U.S. Gov't]. PLoS Biology, 12(7), e1001906. https://doi.org/ 10.1371/journal.pbio.1001906.

208. Kucherlapati, R. (2012). Genetically modified mouse models for biomarker discovery and preclinical drug testing. [Research
Support, N.I.H., Extramural]. Clinical Cancer Research, 18(3), 625-630. https://doi.org/10.1158/1078-0432.CCR-11-2021.

209. Kelly-Spratt, K. S., Kasarda, A. E., Igra, M., \& Kemp, C. J. (2008). A mouse model repository for cancer biomarker discovery. Journal of Proteome Research, 7(8), 3613-3618. https://oi. org/10.1021/pr800210b.

210. Zhang, H., Yi, E. C., Li, X. J., Mallick, P., Kelly-Spratt, K. S., Masselon, C. D., et al. (2005). High throughput quantitative analysis of serum proteins using glycopeptide capture and liquid chromatography mass spectrometry. [Research Support, N.I.H., Extramural Research Support, Non-U.S. Gov't Research Support, U.S. Gov't, Non-P.H.S. Research Support, U.S. Gov't, P.H.S.] Molecular \& Cellular Proteomics, 4(2), 144-155. https:// doi.org/10.1074/mcp.M400090-MCP200.

211. Whiteaker, J. R., Zhang, H., Zhao, L., Wang, P., Kelly-Spratt, K. S., Ivey, R. G., et al. (2007). Integrated pipeline for mass spectrometry-based discovery and confirmation of biomarkers demonstrated in a mouse model of breast cancer. [Research Support, N.I.H., Extramural Research Support, Non-U.S. Gov't]. Journal of Proteome Research, 6(10), 3962-3975. https://doi.org/ $10.1021 / \mathrm{pr} 070202 \mathrm{v}$.

212. Siolas, D., \& Hannon, G. J. (2013). Patient-derived tumor xenografts: transforming clinical samples into mouse models. [Review]. Cancer Research, 73(17), 5315-5319. https://doi.org/ 10.1158/0008-5472.CAN-13-1069.

213. Pitts, T. M., Tan, A. C., Kulikowski, G. N., Tentler, J. J., Brown, A. M., Flanigan, S. A., et al. (2010). Development of an integrated genomic classifier for a novel agent in colorectal cancer: approach to individualized therapy in early development. [Research Support, N.I.H., Extramural Research Support, Non-U.S. Gov't]. Clinical Cancer Research, 16(12), 3193-3204. https://doi.org/10. 1158/1078-0432.CCR-09-3191.

214. Tentler, J. J., Tan, A. C., Weekes, C. D., Jimeno, A., Leong, S., Pitts, T. M., et al. (2012). Patient-derived tumour xenografts as models for oncology drug development. [Review]. Nature Reviews. Clinical Oncology, 9(6), 338-350. https://doi.org/10. 1038/nrclinonc.2012.61.

215. Weroha, S. J., Becker, M. A., Enderica-Gonzalez, S., Harrington, S. C., Oberg, A. L., Maurer, M. J., et al. (2014). Tumorgrafts as in vivo surrogates for women with ovarian cancer. [Research Support, N.I.H., Extramural Research Support, Non-U.S. Gov't]. Clinical Cancer Research, 20(5), 1288-1297. https://doi.org/10. 1158/1078-0432.CCR-13-2611.

216. Hidalgo, M., Bruckheimer, E., Rajeshkumar, N. V., GarridoLaguna, I., De Oliveira, E., Rubio-Viqueira, B., et al. (2011). A pilot clinical study of treatment guided by personalized tumorgrafts in patients with advanced cancer. Molecular Cancer Therapeutics, 10(8), 1311-1316. https://doi.org/10.1158/15357163.MCT-11-0233.

217. Denayer, T., Stohr, T., \& Van Roy, M. (2014). Animal models in translational medicine: validation and prediction. New Horizons in Translational Medicine, 2(1), 5-11. https://doi.org/10.1016/j. nhtm.2014.08.001.

218. Shultz, L. D., Brehm, M. A., Garcia-Martinez, J. V., \& Greiner, D. L. (2012). Humanized mice for immune system investigation: progress, promise and challenges. [Research Support, N.I.H., Extramural Research Support, Non-U.S. Gov't Review]. Nature Reviews. Immunology, 12(11), 786-798. https://doi.org/10.1038/ nri3311.

219. Zhou, Q., Facciponte, J., Jin, M., Shen, Q., \& Lin, Q. (2014). Humanized NOD-SCID IL2rg-/- mice as a preclinical model for cancer research and its potential use for individualized cancer therapies. [Review]. Cancer Letters, 344(1), 13-19. https://doi. org/10.1016/j.canlet.2013.10.015.

220. Tu, C., Rudnick, P. A., Martinez, M. Y., Cheek, K. L., Stein, S. E., Slebos, R. J., et al. (2010). Depletion of abundant plasma proteins 
and limitations of plasma proteomics. [Research Support, N.I.H., Extramural Research Support, Non-U.S. Gov't]. Journal of Proteome Research, 9(10), 4982-4991. https://doi.org/10.1021/ pr100646w.

221. Wilkins, M. R., Appel, R. D., Van Eyk, J. E., Chung, M. C., Gorg, A., Hecker, M., et al. (2006). Guidelines for the next 10 years of proteomics. Proteomics, 6(1), 4-8. https://doi.org/10.1002/pmic. 200500856

222. Righetti, P. G., Boschetti, E., Lomas, L., \& Citterio, A. (2006). Protein equalizer technology: the quest for a "democratic proteome”. [Research Support, Non-U.S. Gov't Review].
Proteomics, 6(14), 3980-3992. https://doi.org/10.1002/pmic. 200500904.

223. Adam, G. C., Sorensen, E. J., \& Cravatt, B. F. (2002). Chemical strategies for functional proteomics. [Research Support, Non-U.S. Gov’t Research Support, U.S. Gov't, P.H.S. Review]. Molecular \& Cellular Proteomics, 1(10), 781-790.

224. Bedard, P. L., Hansen, A. R., Ratain, M. J., \& Siu, L. L. (2013). Tumour heterogeneity in the clinic. [Research Support, N.I.H., Extramural Research Support, Non-U.S. Gov't]. Nature, 501(7467), 355-364. https://doi.org/10.1038/nature12627. 